\title{
DAMAGE AND LOSS PROGNOSIS TOOLS CORRELATING FLOOD ACTION AND BUILDING'S RESISTANCE-TYPE PARAMETERS
}

\author{
H. MAIWALD \& J. SCHWARZ \\ Earthquake Damage Analysis Center (EDAC), Bauhaus Universität Weimar, Germany.
}

\begin{abstract}
The planning and implementation of numerous flood protection measures and the associated cost-benefit studies after the 2002 flood in Germany showed the demand for accurate damage functions. Conventional loss models are limited to the relationship between flood height and the recovery costs for a specific usage class (e.g. private residential buildings). Important parameters on the resistance side such as the building materials and further impact parameters such as flow velocity remain unconsidered.

Following the procedure developed in the risk analysis of earthquakes, it is checked whether methodical fundamentals can be transferred or are to be adopted in case of flood impact and which parameters must be derived from data surveys.

On the basis of a large and uniformly elaborated flood damage database (including different data sets collected by the Earthquake Damage Analysis Center (EDAC) after the 2002 flood in Saxony, Germany), an engineered and vulnerability-oriented prognosis tool was developed to determine the structural damage and the losses for any given flood scenario.

Repeatedly observed damage patterns are transformed into a classification scheme of damage grades. With this tool, the structural damage of many different damage cases can be analysed in a systematic way and related to the parameters describing the flood impact. Vulnerability classes for the different building types are defined by using the data for determining characteristic ranges of damage expectation. Basic steps of the procedure are illustrated for a fictitious data set and subsequently applied to the existing database.

Specific vulnerability and damage functions enable the calculation of damage grades and the loss assessment in separate steps of the same procedure, related to the inundation level or additionally the flow velocity (action side), and the predominant building types or the vulnerability classes (resistance side).

The damage distribution caused by the August 2002 flood can be re-interpreted for study areas with close agreement to the observed effects. A similar good prognosis could be achieved for the reported loss in monetary terms by correlating vulnerability and impact parameters using the recently elaborated specific damage functions. First investigations with respect to the location of buildings, the direction of flow and the structural damage are also represented. This paper gives an overview of the background and the basic steps of the developed procedure and illustrates the different fields of its application.

Keywords: damage functions, damage grades, flood damage, flow velocity, loss estimation, specific energy height, vulnerability classes, vulnerability functions.
\end{abstract}

\section{MOTIVATION}

The flood events of recent years show that even extreme events with very low probabilities of occurrence are possible and can result in devastating damage. It was found that in addition to pure penetration damage, more or less severe structural damage to the building substance can occur. The largest losses for the 2002 flood in Saxony (Fig. 1) can be found in the residential and the commercial sector [1].

In comparison to other areas of hydrology and water management, only few damage data and applicable models are available, which can be used for reliable prediction of flood damage [2]. The planning and implementation of numerous flood protection measures and 


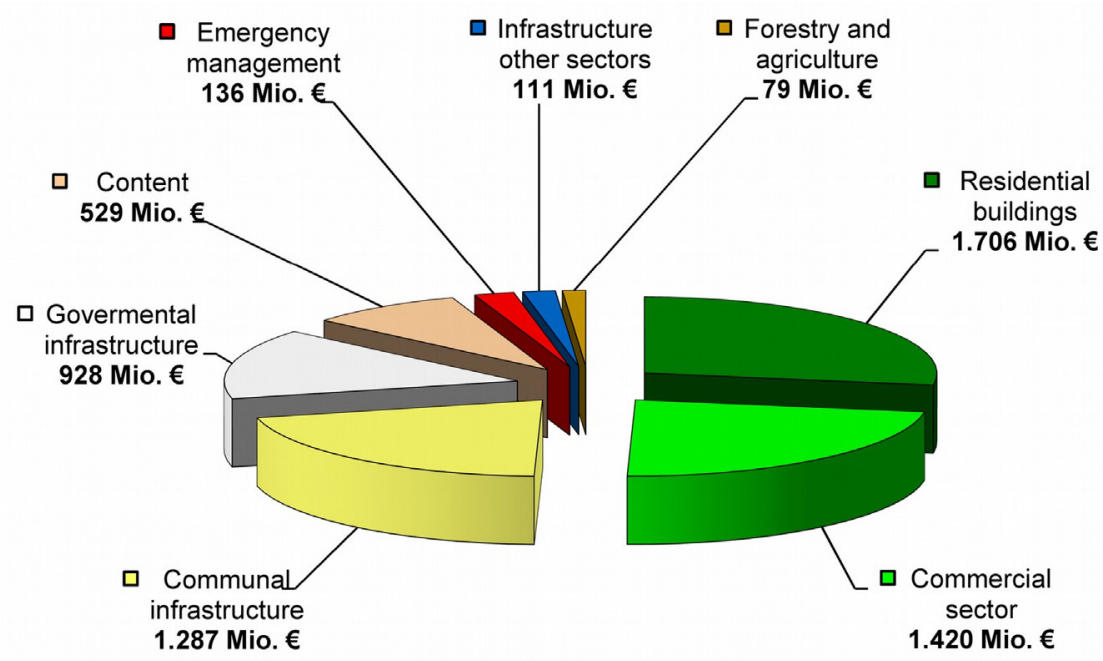

Figure 1: Distribution of losses due to the 2002 flood in Saxony [1].

the associated cost-benefit studies after the 2002 flood showed the demand for more accurate damage functions for each usage class (i.e. residential buildings).

From empirical statistical data analysis, no satisfying damage relationships for Germany are available for the period before the 2002 flood. Hence, there is a trend in recent years in the development of so-called synthetic damage functions [3].

The losses are calculated for characteristic buildings (called representatives) of a building type using a 'what-if' analysis. One investigation for the development of synthetic damage functions for a study area in the UK can be taken from [4]. A German example is the pilot study for the flood protection concept for the town Pirna in Saxony [5].

After the 2002 flood, new extensive damage data are available for the derivation of improved empirical-statistical flood damage models. Conventional flood damage models consider only the relationship between inundation level and the estimated losses for the different sectors of use (e.g. residential or commercial buildings). On the one hand, the differentiation of the resistance parameters is missing; on the other hand, impact parameters, such as the flow velocity, are not considered.

Based on experience with earthquake hazard assessment, a vulnerability-based flood damage model was developed, which can consider these missing parameters. The damage grades, vulnerability classes and vulnerability functions, which are described in the European Macroseismic Scale EMS-98 [6], are transferred to the application for the flood hazard.

On the basis of the EDAC flood database (that includes different data sets collected after the 2002 flood in Saxony), a method was developed to determine the structural damage and the direct tangible losses (cf. [7,8]) for residential buildings (or similar constructions) for any given flood scenario $[9,10]$.

Specific functions enable the calculation of damage grades and loss assessment in separate steps of the same procedure. Specific vulnerability functions (SVF) are related to the inundation level or additionally the flow velocity, and the predominant building types or the vulnerability classes [9-11]. Specific damage functions (SDF) can calculate the expected losses directly under consideration of the inundation level and the predominant building types (SDF Type 1a) or the assigned vulnerability classes (SDF Type 1b) $[9,12,13]$. SDF 
Type 2 transfer damage grades into loss statements $[9,13]$. The developed empirical approach enables the prediction of damage and the identification of areas with particularly vulnerable building structures for given scenarios. Recommendations for future developments can be derived.

In addition to the realistic loss statements, the expected damage grades provide information relevant for disaster management.

The aim of this paper is to present elements of the model and its practical application. Not at least, the validation of observed or reported damage should encourage potential users to follow the engineering approach and to take field surveys and vulnerability assessment as relevant tasks for flood damage prognosis.

\section{CALCULATION SCHEME}

Figures 2 and 3 provide an overview of the calculation process of the engineering-based damage model with the developed vulnerability and damage function types. The red elements highlight the improved model components compared with former conventional approaches. The individual elements of the methodology are discussed in Sections 4-7.

\section{DATABASE}

\subsection{General use of damage data}

The key element of the procedure is the preparation of the real damage cases, which were elaborated immediately after the 2002 flood in Saxony (Figs 4 and 5).

After unification of the data with respect to structural parameters and the transfer into the proposed scheme of damage grades by following the verbal damage description, the data sets can be considered individually and in combination.

The data sets include information about the duration, velocity (in qualitatively descriptive terms like low or high) and other secondary (probably damage contributing) flood actions as well as vulnerability-related parameters.

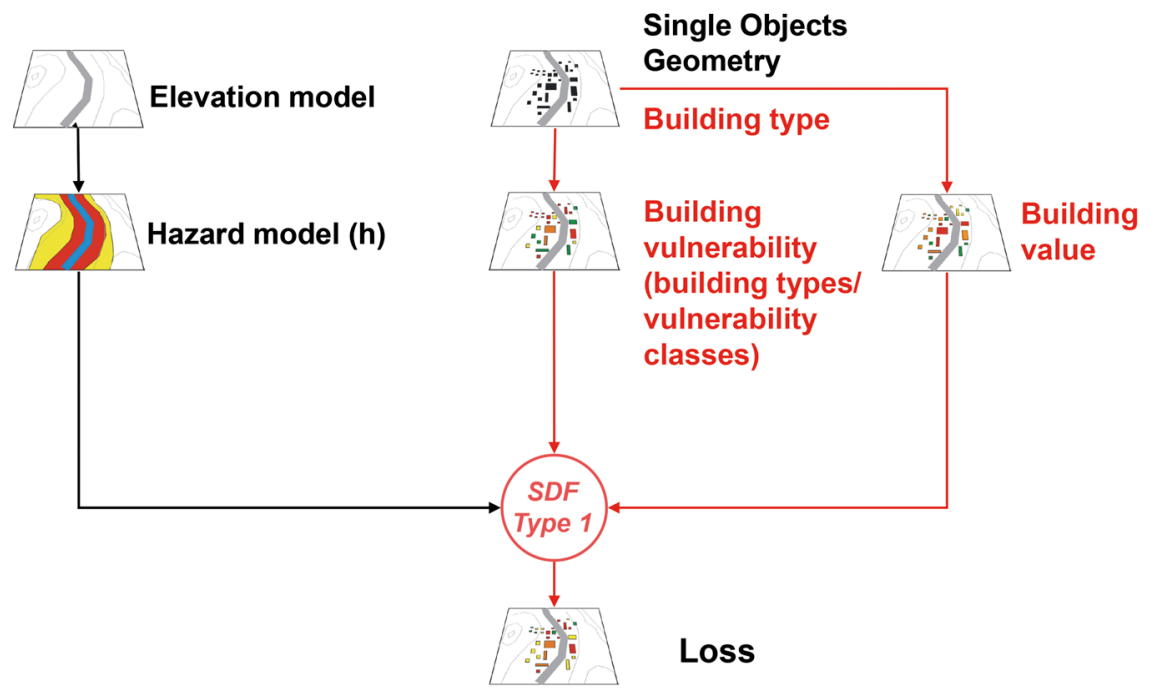

Figure 2: Flow chart of the microscale approach using the SDF Type 1. 


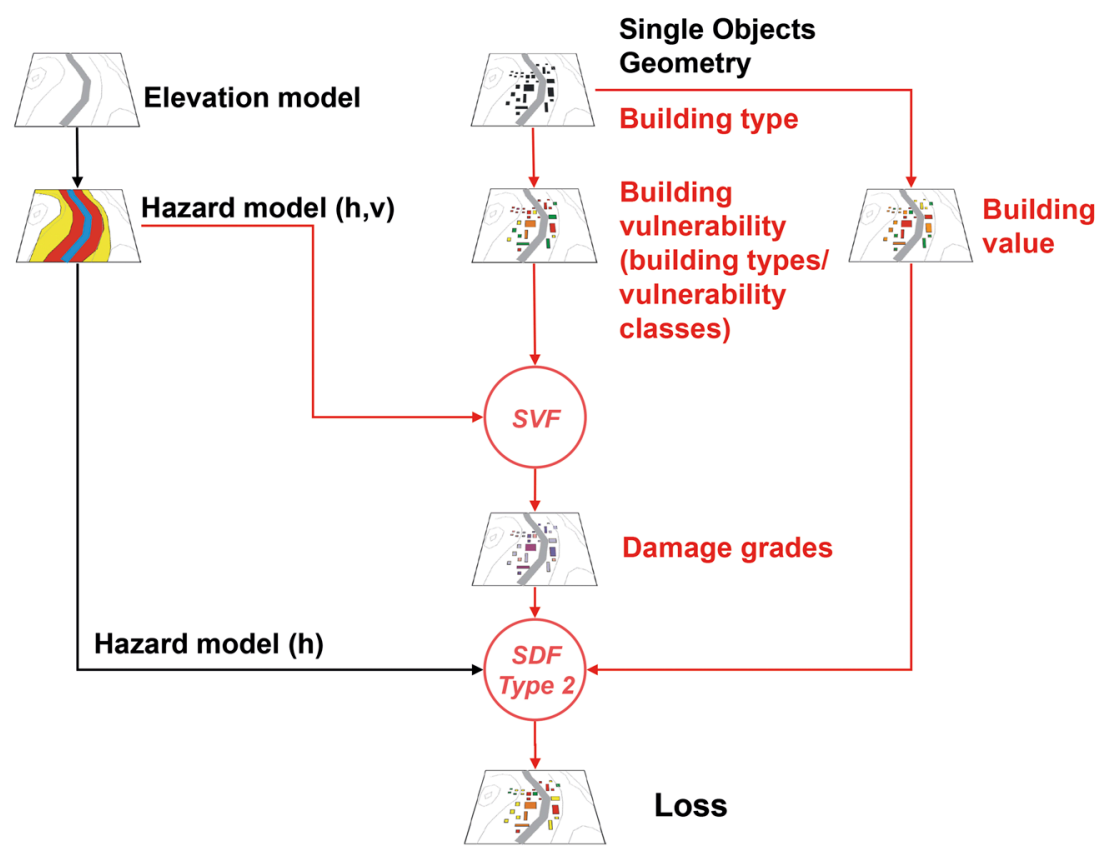

Figure 3: Flow chart of the microscale approach using the SDF Type 2.

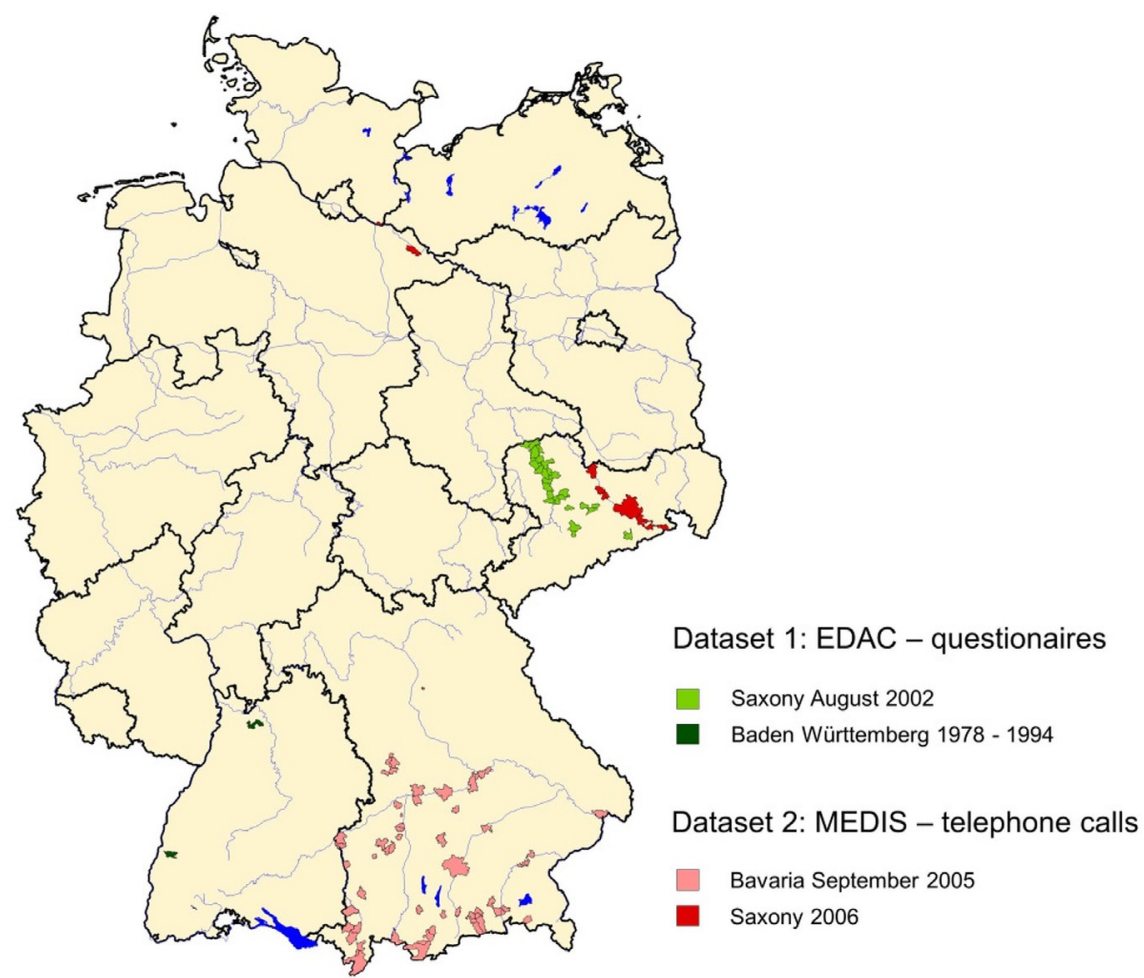

Figure 4: Damage data from different flood events used in this study. 


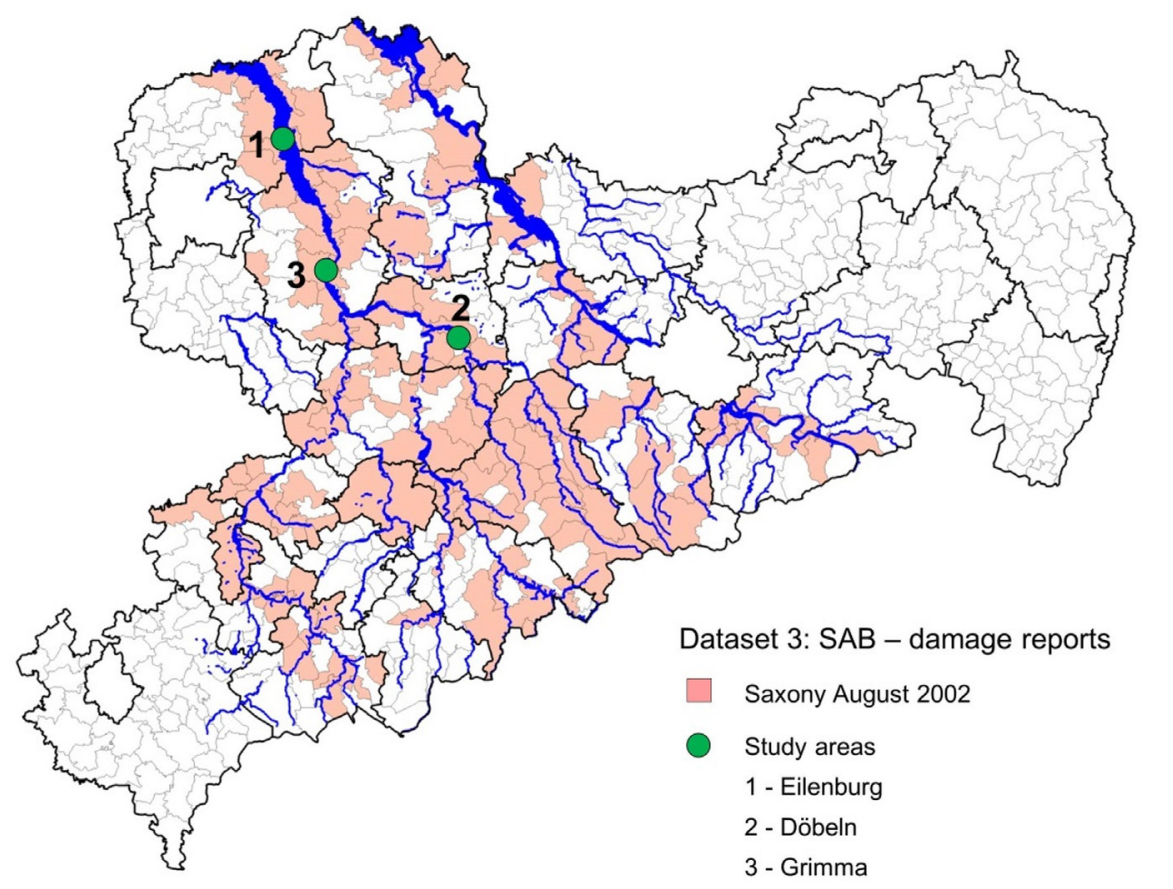

Figure 5: Spatial distribution of data set 3 derived from the affected areas in Saxony during the 2002 flood using SAB damage reports [12].

\subsection{Data set 1}

Data set 1 is related to the outcome of a questionnaire survey performed by the authors between 2002 and 2004 (Fig. 4, cf. [14]) along the river basin of 'Vereinigte Mulde', 'Zschopau' and 'Freiberger Mulde', and is therefore concentrated on the most affected areas during the 2002 flood in Saxony.

The data quality of the responses is good, because a large part of the respondents were able to use the necessary damage reports for subsidy applications by the Saxonian Relief Bank ('Sächsische Aufbaubank' - SAB).

Additional damage data are available from the damage reports of two communal housing associations [11].

\subsection{Data set 2}

Data set 2 is the outcome of telephone calls (performed within the framework of the RIMAX project MEDIS [2]); basic information about structural damages are provided from floods in different regions (2005 Danube flood in Bavaria and 2006 Elbe flood in Saxony).

Data set 1 and 2 are quite complementary with respect to parameter ranges of inherent data points and lead to a well-distributed database (Fig. 7).

Thus, the collected damage data are representative for the residential building stock in the flood areas of Saxony. 


\subsection{Data set 3}

Data set 3 is the outcome of an evaluation of damage reports of the Saxonian Relief Bank for scientific purposes by order of the 'Landestalsperrenverwaltung Sachsen (LTV)' [12]. Damage reports were sighted and analysed anonymously for nearly from all districts in Saxony affected by the 2002 flood. In addition to the relevant building parameters and the inundation levels, the descriptions of the structural damage were evaluated.

Data set 3 is the most comprehensive data acquisition realized by EDAC, yet still is not completely analysed and is therefore considered separately in the following investigations.

Nevertheless due to the differences in the data sets, the derived vulnerability functions have an impact on the predicted results (see Fig. 11).

\section{CLASSIFICATION OF FLOOD DAMAGES}

\subsection{Causes of the damage and factors of influence}

In general, the majority of damage cases are pure penetration damages to buildings for which the inundation level is the most adequate influence parameter.

The rehabilitation measures on the building include mostly drying and cleaning, the repair of technical building equipment (heating, electrical and sanitary equipment) and an average volume of repair measures, which are related to the replacement of doors and windows.

Plasters and floor materials with an adequate damage have to be replaced in the affected area (also for hygienic reasons).

However, the flood damages are not only limited to pure penetration and pollution damage, structural damage to buildings can also occur. By the observation of several hundred heavy damage cases ('danger of collapse' and 'total loss') during the 2002 flood, it is clear that structural damages in various grades up to the collapse of the whole building are possible [15]. Different parameters are relevant for the effects of a flood impact to an affected building. They can be separated into two categories (Table 1). On the one hand, the damage is influenced by the parameters of the action side (impact) and on the other hand by the parameters of the resistance side (vulnerability) of the affected building. Furthermore, depending on their

Table 1: Classification of damage-related parameter $[9,11,16]$.

\begin{tabular}{llll}
\hline Action parameters & & Resistance parameters (vulnerability) \\
\hline Primary & Secondary & Primary & Secondary \\
\hline Inundation level & Bed load and suspended & $\begin{array}{l}\text { Type of construction } \\
\text { Building type(s) }\end{array}$ & $\begin{array}{l}\text { Type of interior } \\
\text { construction }\end{array}$ \\
$\begin{array}{ll}\text { Flow velocity } \\
\text { load }\end{array}$ & Building condition & Building age \\
Specific energy & $\begin{array}{l}\text { Contaminations } \\
\text { Repeated floods } \\
\text { height }\end{array}$ & & \\
Impact of debris (depending on flow velocity) & & \\
Scouring and foundation erosion & & \\
Duration (depending on building type) & & \\
\hline
\end{tabular}


importance for the structural damage, a classification according to primary and secondary factors is possible.

\subsection{Characteristic damage patterns}

Field surveys have to be qualified with respect to the documentation of damage cases and the collection of structural parameters that affect the vulnerability of each building. The documentation has to implement an 'engineering' description of the building and its structural damage, and to determine typical damage patterns. Frequently observed effects are used as indicators for the definition of damage grades. In addition to the structural damage, observed damage-indicating phenomena can be related to chemical or physical origin [10]. For the damage classification, rehabilitation measures are of importance to link the visible actions with the generalized scheme of damage interpretation. Table 2 summarizes the main criteria for the classification of observed effects in an extended and widely applicable format.

\subsection{Definition of damage grades}

For the description of the damages, it is necessary to distinguish between structural and non-structural damages, which can be assigned characteristic damage patterns in the form of

Table 2: Observed damage pattern due to flood impact and classification criteria $[10,17]$.

\begin{tabular}{|c|c|c|c|c|c|c|}
\hline \multirow{2}{*}{ Criteria } & \multirow{2}{*}{ Observed effect/measure } & \multicolumn{5}{|c|}{ Damage grade Di } \\
\hline & & D1 & D2 & D3 & D4 & D5 \\
\hline $\begin{array}{l}\text { Building physical } \\
\text { damage }\end{array}$ & $\begin{array}{l}\text { Penetration of supporting and non- } \\
\text { structural walls and the floor slabs }\end{array}$ & 0 & $\times$ & $\times$ & $\times$ & $x$ \\
\hline \multirow{2}{*}{$\begin{array}{l}\text { Chemical } \\
\text { damage }\end{array}$} & Pollution (mud, excrements, etc.) & $x$ & $x$ & $x$ & $x$ & $x$ \\
\hline & Contamination (oil and chemicals) & & $x$ & $\times$ & $\times$ & $\times$ \\
\hline \multirow{6}{*}{$\begin{array}{l}\text { Structural } \\
\text { damage }\end{array}$} & Impressed doors and windows & & $\times$ & $\times$ & $\times$ & $\times$ \\
\hline & Slight cracks in structural elements & & $x$ & $\times$ & $\times$ & $\times$ \\
\hline & $\begin{array}{l}\text { Major cracks and/or deformations in } \\
\text { structural walls and slabs }\end{array}$ & & & ○ & $\times$ & $\times$ \\
\hline & Settlements & & & $\times$ & $\times$ & $\times$ \\
\hline & $\begin{array}{l}\text { Partial failure of primary structural } \\
\text { elements (load-bearing walls and slabs) }\end{array}$ & & & & $\bigcirc$ & $\times$ \\
\hline & Collapse of major parts of the building & & & & & O \\
\hline \multirow{5}{*}{$\begin{array}{l}\text { Rehabilitation } \\
\text { measures }\end{array}$} & Cleaning of penetrated elements & $\bigcirc$ & $\times$ & $x$ & $\times$ & $x$ \\
\hline & Replacement of extension elements & & O & $\times$ & $\times$ & $\times$ \\
\hline & Replacement of non-structural elements & & & $x$ & $\times$ & $\times$ \\
\hline & Replacement of structural elements & & & & $x$ & $x$ \\
\hline & Demolition of building required & & & & & $x$ \\
\hline
\end{tabular}

Note $: \times=$ observed damage could occur to corresponding damage grade;

$\bigcirc=$ characteristic criteria for a qualitatively higher damage grade. 
damage grades. The damage according to the EMS-98 [6] for earthquakes is divided into damage grades: from D0 (no damage) to D5 (collapse). However, this concept of the EMS-98 cannot be directly applied to flood damages [10], because:

- In addition to the structural damage due to flood action, the larger part of pure penetration damages have to be considered.

- For seismic action, no clear boundary of the affected area can be found. All the buildings of an area are more or less affected by the earthquake waves. According to the level of impact (intensity) and their vulnerability, the buildings will be damaged in different grades. It is also possible that buildings can survive the earthquake undamaged (damage grade D0).

- A flood impact is linked to the topography of the terrain. The affected building stock can be clearly separated from the unaffected one. In general, locally elevated buildings within a flooded area are unaffected as long as they are not directly influenced by the water. For flood impact, the consideration of damage grade D0 is therefore not required. The minimum damage grade for affected (penetrated) buildings is D1.

- For buildings that are only affected slightly by the floods (with no or only small financial loss), a certain amount of effort is required for damage repair (cleaning and drying measures). These limiting cases should already be assigned a damage grade D1 (only penetration).

The compilation of the observed effects and measures in Table 2 allows the derivation of the descriptions for each damage grade according to the scheme in Table 3. The damage grade is qualified in the sequence to the:

- Structural damage.

- Building physical damage.

- Chemical damage.

- Amount of rehabilitation measures.

Only the additional observed effects are specified as an indicator for the corresponding higher damage grades [10]. In practical application, the appropriate damage grade can be assigned for each damage case, and it is sufficient if one of the features listed in Table 3 is observed (after the event) or mentioned (e.g. in subsequent questionnaires [14]).

The description of the damage grades D2 and D5 needs a closer examination [10]: penetration damages on non-structural elements (e.g. doors, windows, floor screeds, drywalls, etc.) result often in the loss of their function or in health risks. The penetration of water can cause a destruction of the 'structure' resulting in a replacement of building elements. In the broadest sense, these types of penetration damages are also a type of the structural damage. In terms of monetary losses, these damages should be separated from damage grade D1. They should be assigned to damage grade D2. To illustrate the problem, the financial costs to replace a complete door including the frame are examined: from the cost point of view, it is irrelevant whether the door was pushed in by the flood action or became useless by the penetration. According to this argumentation, a flood damage which requires a demolition of a building (e.g. due to a heavy oil contamination) has to be considered as a total loss and assigned to damage grade D5 (Table 3). 
Table 3: Assignment of damage grades Di to damage cases [10,17,18].

\begin{tabular}{|c|c|c|c|c|}
\hline $\mathrm{Di}$ & $\begin{array}{l}\text { Damage } \\
\text { Structural } \\
\text { Non- } \\
\text { structural }\end{array}$ & Description & Drawing & Example \\
\hline D1 & $\begin{array}{l}\text { No } \\
\text { Slight }\end{array}$ & $\begin{array}{l}\text { Only penetration and } \\
\text { pollution }\end{array}$ & & \\
\hline D2 & $\begin{array}{l}\text { No to slight } \\
\text { Moderate }\end{array}$ & $\begin{array}{l}\text { Slight cracks in } \\
\text { supporting elements } \\
\text { Impressed doors and } \\
\text { windows } \\
\text { Contamination } \\
\text { Replacement of } \\
\text { extension elements }\end{array}$ & & \\
\hline D3 & $\begin{array}{l}\text { Moderate } \\
\text { Heavy }\end{array}$ & $\begin{array}{l}\text { Major cracks and/or } \\
\text { deformations in } \\
\text { supporting walls and } \\
\text { slabs } \\
\text { Settlements } \\
\text { Replacement of non- } \\
\text { supporting elements }\end{array}$ & & \\
\hline D4 & $\begin{array}{l}\text { Heavy } \\
\text { Very heavy }\end{array}$ & $\begin{array}{l}\text { Structural collapse of } \\
\text { supporting walls, slabs } \\
\text { Replacement of } \\
\text { supporting elements }\end{array}$ & & \\
\hline D5 & $\begin{array}{l}\text { Very heavy } \\
\text { Very heavy }\end{array}$ & $\begin{array}{l}\text { Collapse of the building } \\
\text { or of major parts of the } \\
\text { building } \\
\text { Demolition of building } \\
\text { required }\end{array}$ & & \\
\hline
\end{tabular}

\section{INTRODUCTION OF VULNERABILITY CLASSES AND DERIVATION OF VULNERABILITY FUNCTIONS}

\subsection{General concept}

According to EMS-98 [6] for earthquake damages, the building stock should be classified into building types, for which corresponding vulnerability classes are indicated. 
Based on the experience with seismic action and in anticipation of the feedback of modern earthquake codes, the building types are divided into six vulnerability classes (A-F), indicated for each representative building type (e.g. for masonry vulnerability class B).

Vulnerability classes subsume the event-specific vulnerability (or resistance) in the form of occurrence of similar damage grades (in quantity and quality), under the same impact intensities; they summarize structures of the same vulnerability.

Vulnerability classes are a measure of the behaviour under the effects of the impact or the resistance against it. Vulnerability class A is representative for buildings with the largest expected damages; the buildings of vulnerability class F should survive strong earthquakes without significant damage. (This is done only by earthquake-resistant design.)

There is a scatter of possible vulnerability for each building type:

- most likely vulnerability class,

- probable range and

- range of less, probable, exceptional cases.

The most likely class and the range of scatter follow from a variety of damage assessments; they are expressed by characteristic symbols, which are adopted unchanged in the floodvulnerability table (cf. Table 5). The ranges of scatter may be different in both directions (lower or higher vulnerability), or even tend only in one direction. The specific classification within the range of scatter depends on the condition and the structural design of the building.

Main elements of vulnerability under predominant horizontal oriented impact loads are the vertical support members, i.e. for the predominant building types, the load bearing walls and their construction variants. The expected value of structural damage for the corresponding building types can be characterized as the mean damage grade $\mathrm{D}_{\mathrm{m}}$ (see also $[10,19]$ ).

From the damage grades Di of the damage data (Table 3 ), a mean damage grade $\mathrm{D}_{\mathrm{m}}$ can be determined for the various building types within selected impact level intervals (for flood: inundation level intervals $\Delta \mathrm{h}$ ). The general approach for a natural hazard was initially illustrated on the basis of a fictitious database (set of points in Fig. 6a).

The mean damage grades $\mathrm{D}_{\mathrm{m}}$ of the individual building types within an impact level interval can be separated from each other within defined areas (Fig. 6b and c). Depending on the composition of the database, the most probable vulnerability class and the corresponding range of scatter could be characterized within these defined areas for each building type [19].

The characteristic vulnerability class for an unclassified building type is found if the mean damage grade $\mathrm{D}_{\mathrm{m}}$ (correlating to observations) for certain impact levels (for flood: the inundation level) is located within the corresponding area (Fig. 6d). With it, also the scatter in the vulnerability within a main building type (by qualitatively different construction, building materials, etc.) can be taken into account.

Building types of similar vulnerability can be summarized in a representative curve for these areas, the vulnerability function. The vulnerability functions for the individual building types (Fig. 6e) can be derived by a nonlinear regression procedure. The assignment of the damage cases in vulnerability classes ('HW classes' for flood application) enables the calculation of vulnerability functions for the defined vulnerability classes (Fig. 6f). 


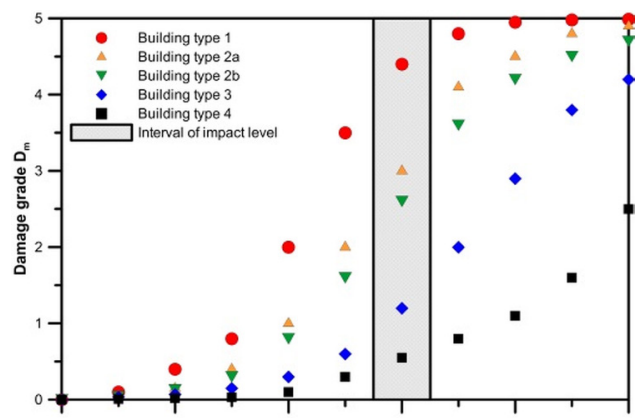

(a)

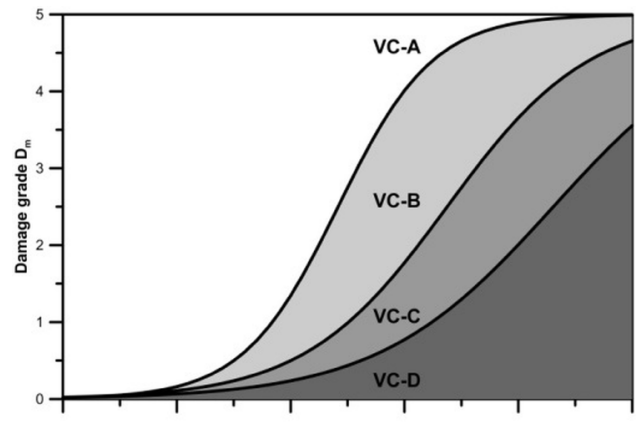

Impact level

(c)

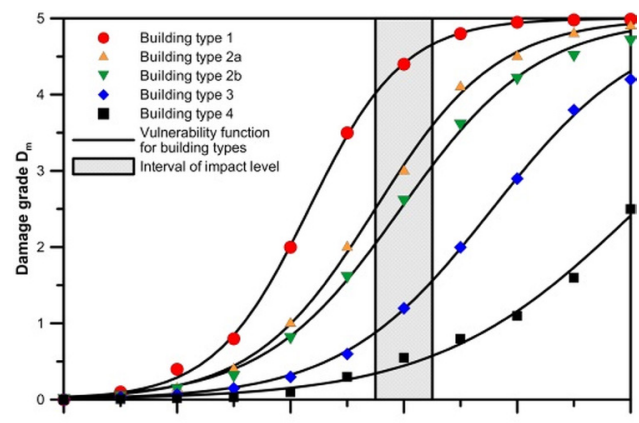

(e)

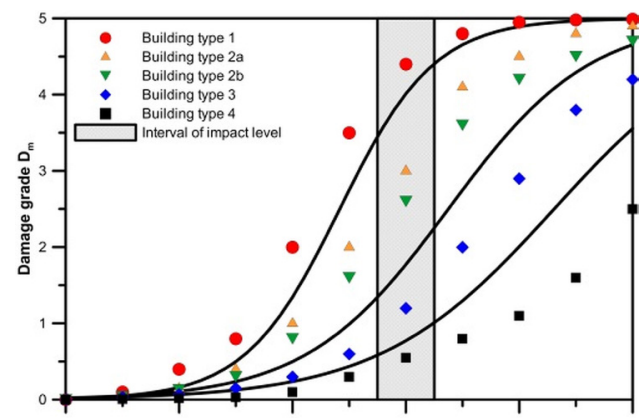

(b)

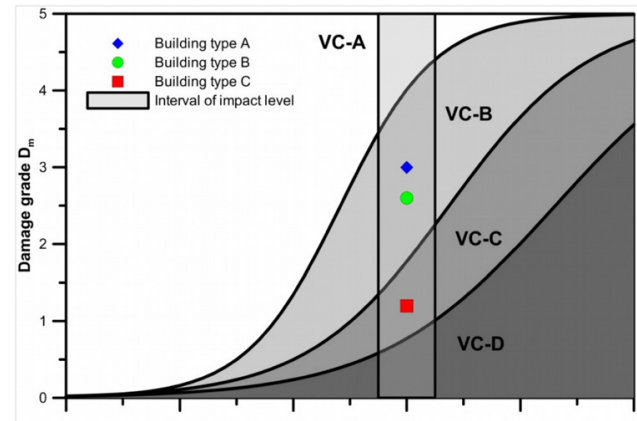

(d)

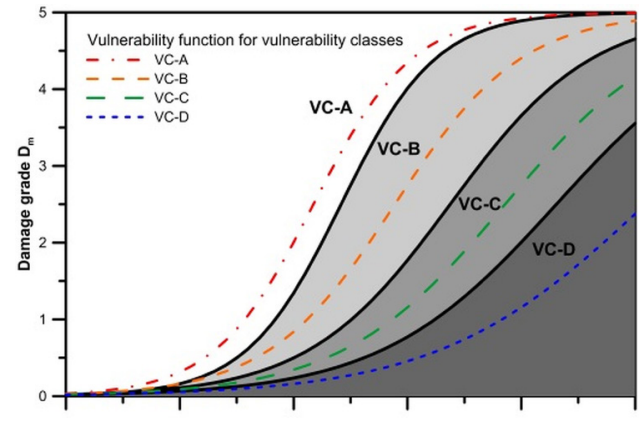

(f)

Figure 6: General concept for the classification of vulnerability classes and the derivation of vulnerability functions (on the basis of a fictitious data set; cf. [19]). (a) Calculation of mean damage grade $\mathrm{D}_{\mathrm{m}}$; (b) Separation of vulnerability levels; (c) transfer into vulnerability classes; (d) mean damage grades $\mathrm{D}_{\mathrm{m}}$ of main building type in a defined impact level interval; (e) derivation of vulnerability functions for building types; and (f) vulnerability functions for vulnerability classes. 
Table 4: Classification of building types in vulnerability classes (general description).

\begin{tabular}{|c|c|c|c|c|c|}
\hline \multirow{2}{*}{$\begin{array}{l}\text { Classification of building types } \\
\text { Description }\end{array}$} & \multicolumn{5}{|c|}{ Flood vulnerability class HW- } \\
\hline & A & $\mathrm{B}$ & $\mathrm{C}$ & $\mathrm{D}$ & $\mathrm{E}$ \\
\hline \multicolumn{6}{|l|}{ Highly sensitive } \\
\hline \multicolumn{6}{|l|}{ Sensitive } \\
\hline \multicolumn{6}{|l|}{ Normal flood resistance } \\
\hline Increased flood resistance & & & & & \\
\hline Flood resistant design & & & & & \\
\hline
\end{tabular}

\subsection{Application for flood}

Vulnerability classes can be categorized differently. A building type based classification (Table 5) should be preferred as opposed to an idealized classification (Table 4) with respect to the resistance to flood impact. With the prepared database (Figs 7 and 8a), vulnerability levels can be separated on the basis of the mean damage grade $\mathrm{D}_{\mathrm{m}}$ for the individual building types in unique flood level intervals (here $\Delta \mathrm{h}=0.5$, cf. Fig. $8 \mathrm{~b}$ ).

For the normal building stock, four flood vulnerability classes will be introduced (HW-A to HW-D). Each of these flood vulnerability classes represents building types with a similar vulnerability. In addition, a flood vulnerability class HW-E is proposed to take into account (rule-compliant) buildings with a significantly increased flood resistance. Class HW-E buildings (as recommended in common guidelines) are characterized by a separation of buildings from the flood water table, for instance, by raising the ground floor onto story-high columns (cf. Fig. 10a). In the case of flooding, only the uninhabited parts of the building (the entrance area as in Fig. 10b) would be affected [20].

The vulnerability level for vulnerability class HW-E has to be specified by future damage data:

- for buildings constructed in such a flood-resistant design, damage grade D1 (no structural damage, only penetration) might be appropriate, and

- for higher water levels a mean damage grade $\mathrm{D}_{\mathrm{m}}$ only slightly higher than 1 should be expected.

Figure 9 illustrates on the example of masonry buildings the influence of the composition of different damage data sets. It can be shown that the increase in the amount of damage data can result in some changes by the determination of these vulnerability levels. A classification of the predominant building types can be done (Table 5). A differentiation into subbuilding types (e.g. different types of stones and mortar by masonry buildings) needs further research [10]. 


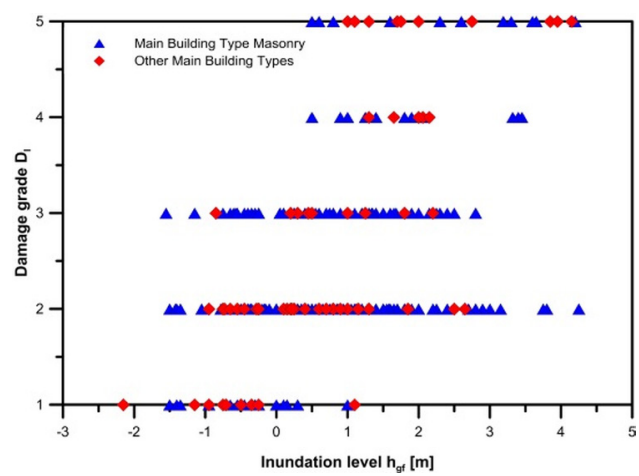

(a)

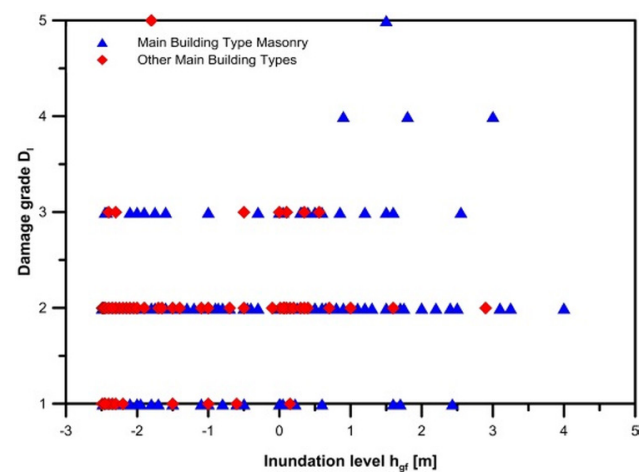

(b)

Figure 7: Distribution of damage grades in dependance of inundation level over ground floor level $h_{\mathrm{gf}}$ ' (a) data set 1 'EDAC' and (b) data set 2 'MEDIS'.

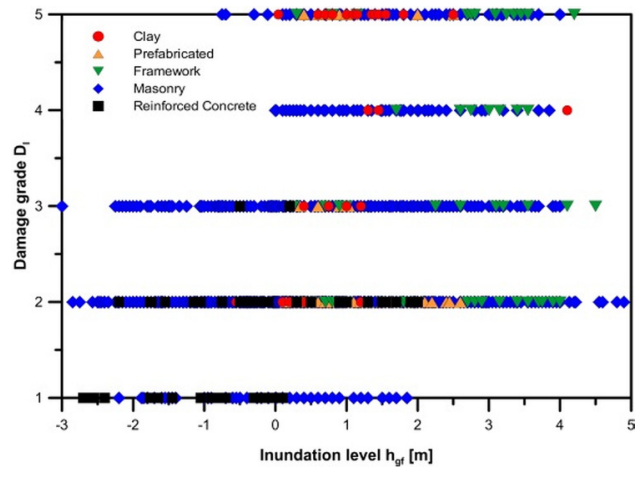

(a)

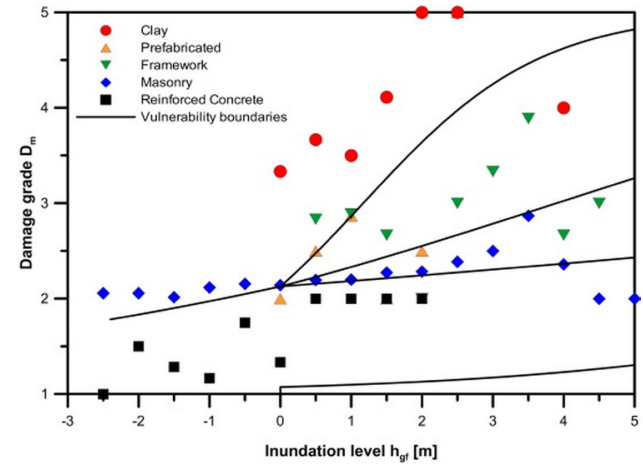

(b)

Figure 8: Composition and analysis of dataset 3: (a) damage grades Di $\left(h_{\mathrm{gf}}\right)$ and (b) mean damage grades $\mathrm{D}_{\mathrm{m}}$ and separation of vulnerability levels.

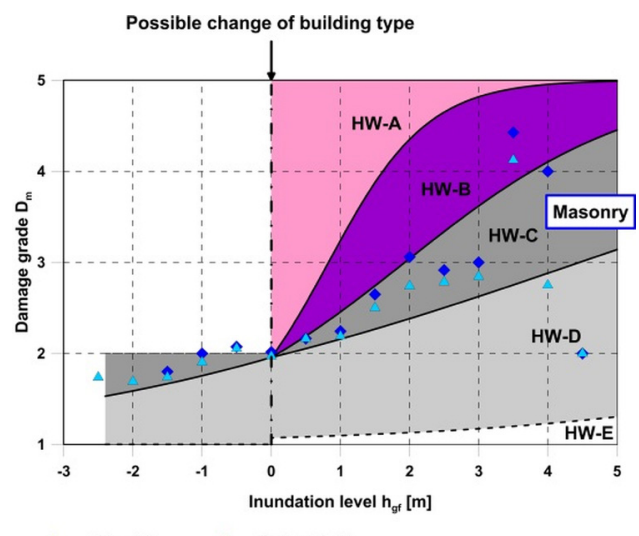

(a)

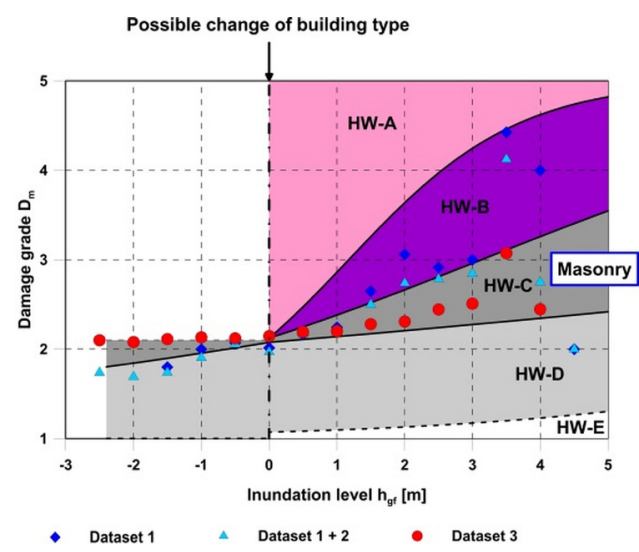

(b)

Figure 9: Mean damage grades $\mathrm{D}_{\mathrm{m}}$, inundation level and vulnerability classes; results for masonry buildings: (a) State 2008 [17] and (b) State 2012 [18]. 
Table 5: Classification of building types in vulnerability classes and identification of ranges of scatter (on the basis of the evaluated data).

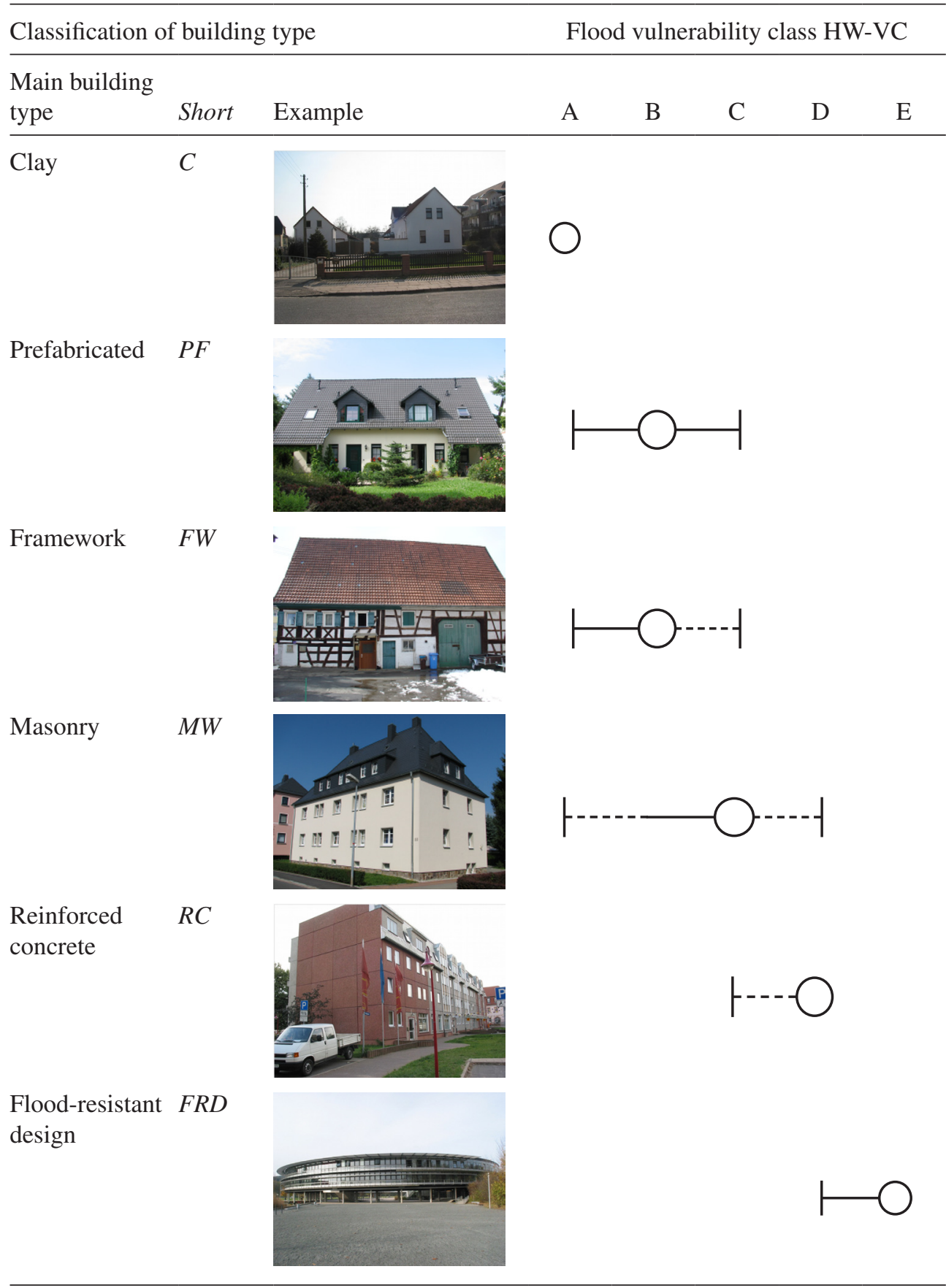

Most likely vulnerability class.

- Probable range.

-- Range of less probable, exceptional cases. 


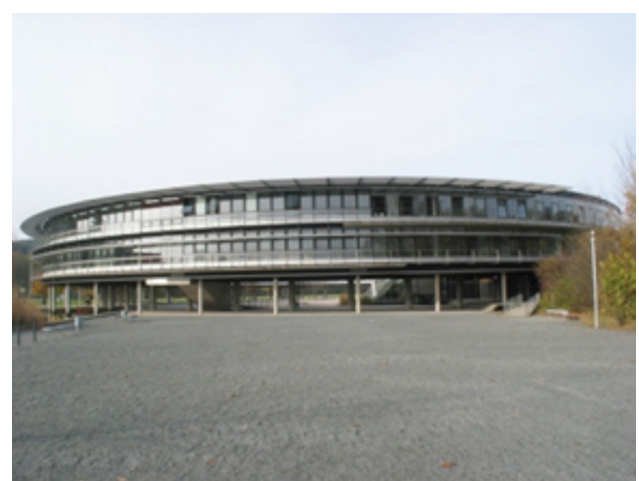

(a)

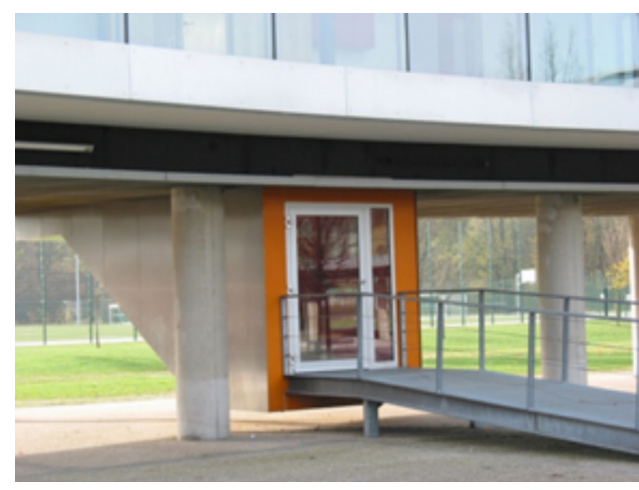

(b)

Figure 10: Flood resistant design (HW-E): (a) secondary school in Flöha (Saxony) and (b) detail entrance.

\section{PROGNOSIS OF DAMAGE GRADES WITH VULNERABILITY FUNCTIONS}

\subsection{Basic characteristics of SVF}

For calculation of the mean damage grade $\mathrm{D}_{\mathrm{m}}$, different vulnerability functions (in the EDACflood damage model denoted by 'Specific Vulnerability Functions' - SVF; cf. Table 6) are available $[9,10,11,21]$.

The mathematical approach of the vulnerability functions is assumed as a tangent hyperbolic function (tanh), which has function values (like the damage grade Di) in a limited range (cf. eq. 1).

Taking into account the definition range of the damage grades Di ( $i=1-5)$ yields the following general expression for the vulnerability functions $[9,10,11]$ :

$$
\mathrm{D}_{\mathrm{m}}=2 \cdot \tanh (\mathrm{f}(\mathrm{x}))+3
$$

For $\mathrm{f}(\mathrm{x})$, a simple linear approach is used:

$$
\begin{gathered}
\mathrm{D}_{\mathrm{m}}=2 \cdot \tanh (\mathrm{A} \cdot \mathrm{x}+\mathrm{B})+3 \\
\mathrm{x}=h_{\mathrm{gf}} \text { or } \mathrm{H}
\end{gathered}
$$

$\mathrm{A}$ and $\mathrm{B}$ are the control parameters of the function. They are determined from the damage data as regression variables and allow the flexible adaptation of the functions. The mean damage grades $\mathrm{D}_{\mathrm{m}}$ according to Eq. (2) depends on the inundation level over the ground floor $h_{\mathrm{gf}}$ or the specific energy height $H$ (Eq. 4), respectively.

6.2 Correlation between mean damage grade $\mathrm{D}_{\mathrm{m}}$ and inundation level $h_{\mathrm{gf}}$

To calculate the mean damage grade $\mathrm{D}_{\mathrm{m}}$ different vulnerability functions for the predominant building types (SVF Type 1a) or for the assigned vulnerability classes (SVF Type 1b) are 
published. These function types take into account the inundation level over the ground floor $h_{\mathrm{gf}}$ as impact parameter $[9,10,11,21]$.

Evaluations based on Data sets $1+2$ for SVF Type 1a are given in Fig. 11a [9,21]. Actual results for the analysis of Data set 3 are presented in Fig. 11b. The differences in the functions come from the different amount of data in the data sets and their composition. For the derivation of the different SVF Type 1b, the appropriate building characteristics (building type,

Table 6: Types of specific vulnerability functions - SVF.

\begin{tabular}{lll}
\hline SVF type & Vulnerability parameter & Impact parameter \\
\hline $1^{*}$ & - & Inundation level over ground floor level $h_{\mathrm{gf}}$ \\
$1 \mathrm{a}$ & Building type & \\
$1 \mathrm{~b}$ & Vulnerability class & \\
$2^{*}$ & - & Inundation level over ground level $h_{\mathrm{gl}}$ \\
$2 \mathrm{a}$ & Building type & + flow velocity $v_{\mathrm{fl}}$ \\
$2 \mathrm{~b}$ & Vulnerability class & $\Rightarrow$ specific energy height $H$ \\
\hline
\end{tabular}

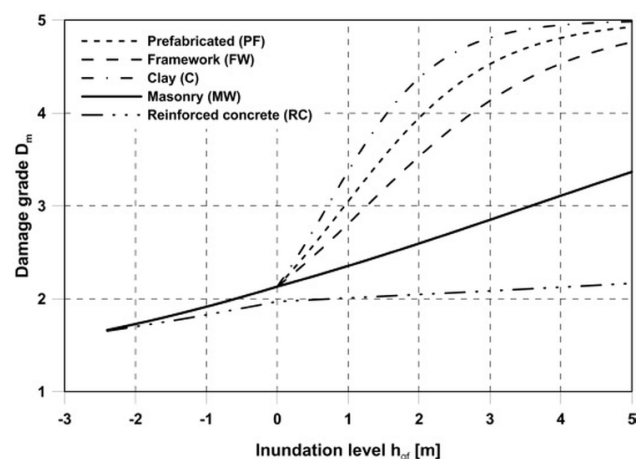

(a)

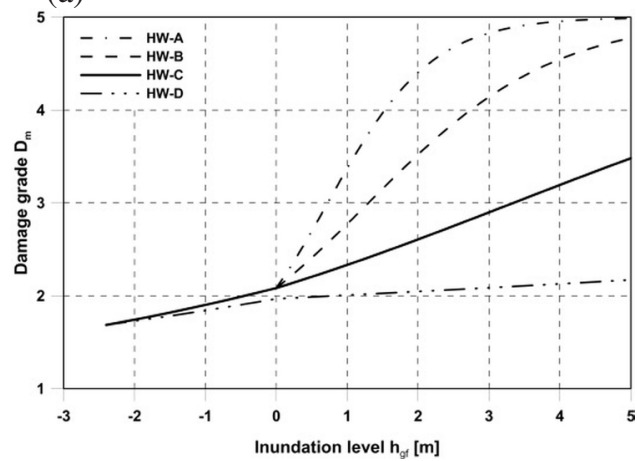

(c)

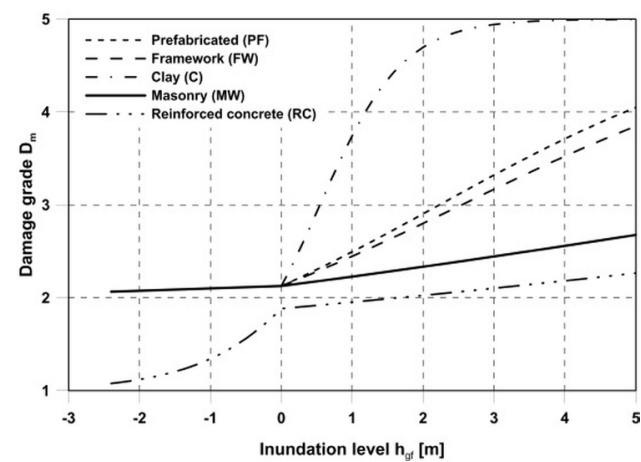

(b)

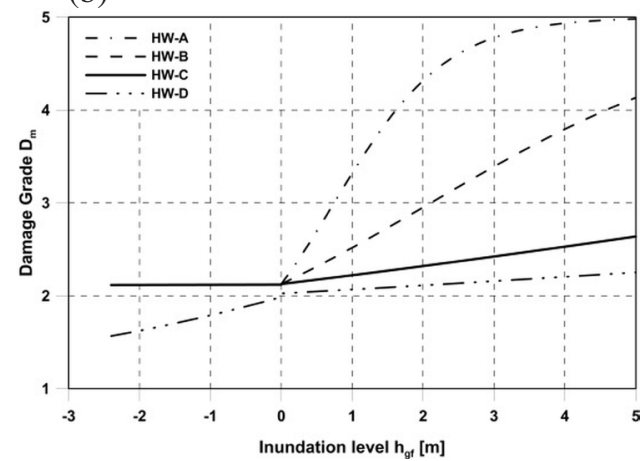

(d)

Figure 11: Specific vulnerability functions of type: $\mathrm{D}_{\mathrm{m}}=\mathrm{f}\left(h_{\mathrm{gf}}\right)$ : (a) SVF Type 1a: data set $1+2$ [9,21]; (b) SVF Type 1a: data set 3; (c) SVF Type 1b: data set $1+2$ [9,21]; and (d) SVF Type 1b: data set 3. 
building condition, etc.) for the classification in vulnerability classes are considered in a uniform approach.

Vulnerability functions for the corresponding flood vulnerability classes are derived (Fig. 11c and d), which can consider the real conditions related to the scatter in the vulnerability of the buildings (see Table 5) in a better way.

Hence, depending on the available data base, the corresponding functions can be applied.

The parameters A and B (Eq. 1 and 2) for a calculation using the developed vulnerability functions with respect to data set $1+2$ can be taken from Ref. [9].

\subsection{Correlation between mean damage grade $\mathrm{D}_{\mathrm{m}}$ and the specific energy height $H$}

The influence of the flow velocity can be important for storm floods on the coast (especially by dam failures), by tsunamis and by so-called 'Flash Floods' in mountain areas. In combination with high flow velocities, heavy structural damage can occur, which can cause extraordinarily high financial losses.

The influence of the flow velocity on the expected loss is considered in simple approaches by referring to distance-depending zones [22]. By analytical studies due to tsunami impact or for design purposes [23], the flow velocity is taken into account for the individual load components (surge, drag, impact and hydrostatical forces). Further analytical studies for predicting the wall failure and other structural damages, taking into account hydrodynamic loads, can be found in $[24,25]$.

In former studies [26-28], the impact of the flow velocity and the building type was investigated mainly in relation to a collapse of the building and accordingly additional criteria for a partial failure of the building were determined. However, a refined differentiation for consideration of the different damage patterns of structural damages and the transfer into realistic loss statements cannot be found in these studies.

Similar approaches to estimate the collapse of the buildings are now included in the HAZUS-MH software provided by the Federal Emergency Management Agency of the United States [29,30]. In the case of collapse, a total loss (100\% of building's value) has to be assumed [31]. A refined consideration of losses considering different levels of structural damage is still missing.

A more interpretive parameter for the determination of such criteria is the flood intensity $I_{\mathrm{fl}}$, which is based on the so-called 'Swiss model' [31]. Here, the damage effects are classified in three stages (Table 7). The flood intensity $I_{\mathrm{fl}}$ follows from the inundation level above ground level $h_{\mathrm{gl}}$ or from the product of inundation level $h_{\mathrm{gl}}$ and flow velocity $v_{\mathrm{fl}}$ (see Eq. 3 ). This approach is recommended in the current guidelines for the design of hazard maps and flood protection concepts [32]

Table 7: Definition of flood intensity [31].

\begin{tabular}{lll}
\hline & \multicolumn{2}{c}{ Classification criteria } \\
\cline { 2 - 3 }$I_{\mathrm{fl}}$ (Intensity) & Inundation level $h_{\mathrm{gl}}[\mathrm{m}]$ & $h_{\mathrm{gl}} \cdot v_{\mathrm{fl}}\left(\mathrm{m}^{2} / \mathrm{s}\right)$ \\
\hline I (weak) & $<0.5$ & $<0.5$ \\
II (medium) & $0.5 \leq h_{\mathrm{gl}} \leq 2.0$ & $0.5 \leq h_{\mathrm{gl}} \cdot v_{\mathrm{fl}} \leq 2.0$ \\
III (strong) & $>2.0$ & $>2.0$ \\
\hline
\end{tabular}




$$
I_{\mathrm{fl}}=h_{\mathrm{gl}} \cdot v_{\mathrm{fl}}
$$

Investigation of different impact parameters which take into account the flow velocity is presented in [33]. It can be shown that the specific energy height $H$ (Eq. 4) has the best correlations to the losses and the structural damages on residential buildings, even when these relationships are poorly visible due to comparatively moderate flow velocities in the existing data sets.

The basic methodology [9,10] can also be applied to the specific energy height $\mathrm{H}$ as an impact parameter (see Eq. 1 and 2). This type of vulnerability function is denoted by SVF Type 2 [13]

$$
\mathrm{H}=h_{\mathrm{gl}}+\frac{v_{\mathrm{fl}}^{2}}{2 \mathrm{~g}}
$$

The flow velocities were derived from hydraulic calculations for re-interpretation of the 2002 flood event in some of the affected areas and were assigned to the damage data [13].

A first model approach, which describes the relationship between the mean damage grade $\mathrm{D}_{\mathrm{m}}$ as a measure of the structural damage and the specific energy height $H$ with vulnerability functions (SVF Type 2*), can be taken from [17]. This approach was refined in [13] and transferred to the loss level.

Figure 12a shows the first results of the analysis for data set 1 [17]. Preliminary vulnerability functions for vulnerability classes (SVF Type $2 b$ ) based on data set 3 are presented in Fig. 12b [9].

Due to the small number of damage data, the vulnerability function for vulnerability class HW-A should be regarded as an engineering-based assumption.

The starting values for the damage grades $\mathrm{D}_{\mathrm{m}}$ at $H=0 \mathrm{~m}$ result mostly from flooding in the basement, since $80 \%$ of the analysed damage cases are related to buildings with a basement.

Normally, the vulnerability classes HW-A and HW-B (with the corresponding building types: clay, framework and prefabricated) cannot be found in the basement level. Therefore, the corresponding vulnerability functions in Fig. 12b are only specified for a specific energy height $H \geq 0.5 \mathrm{~m}$. The characterization of the qualitative features of the curve for $H<0.5 \mathrm{~m}$ remains to be determined from a larger database with linked flow velocity data.

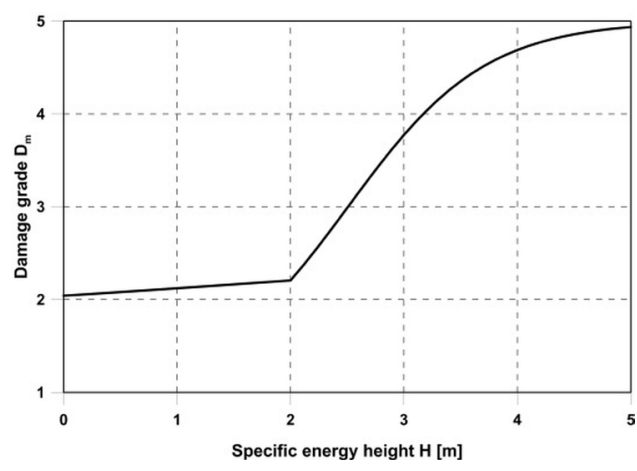

(a)

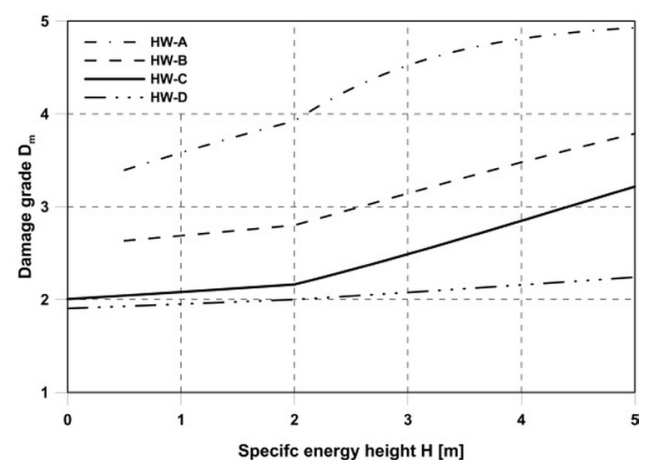

(b)

Figure 12: Specific vulnerability functions of type: $\mathrm{D}_{\mathrm{m}}=\mathrm{f}\left(h_{\mathrm{gl}}, v_{\mathrm{fl}}\right)$ : (a) SVF Type $2 *$ : data set 1 [17] and (b) SVF Type 2b: data set $3[9,13]$. 


\subsection{Location SVF (LSVF)}

The location of the building relative to the flow velocity vector (flow direction) and the urban integration of the building have an influence on the structural damage.

Table 8 shows a preliminary proposal for the classification of the relevant situations from an engineering point of view of a building. These situations are related to the arrangement of surrounding housing and the particular flow characteristic during flood events [13].

Real settlement structures are usually complex; therefore, a simplified classification scheme does not cover all situations. For example, if the flow directions change during a

Table 8: Classification scheme with respect to the location of a building and its exposure to the flow direction $[13,18]$.

\begin{tabular}{llll}
\hline Nr. & Type/Location & Description & Flow direction \\
\hline 1 & Stand alone & & Directly \\
$2 \mathrm{a}$ & Front house & Beginning of a row of houses & Directly/flow around \\
$2 \mathrm{~b}$ & End house & End of a row of houses & Flow around/circulation \\
$2 \mathrm{c}$ & Front/end house & Beginning/end of a row of houses & Orthogonally/circulation \\
$3 \mathrm{a}$ & Central house & In the middle of a row of houses & Tangentially \\
$3 \mathrm{~b}$ & Central house & In the middle of a row of houses & Directly/orthogonally \\
4 & Corner house & Cross situation & Flow around/circulation \\
\hline
\end{tabular}

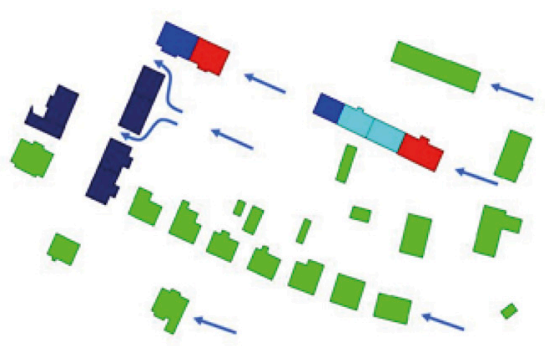

(a)

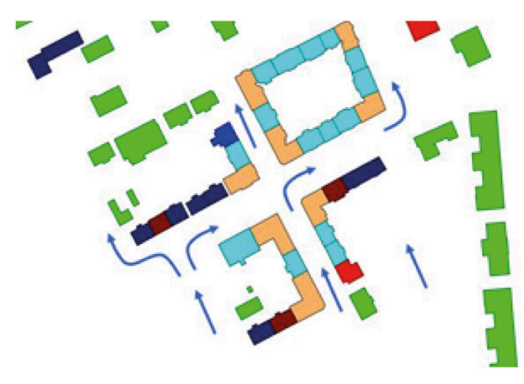

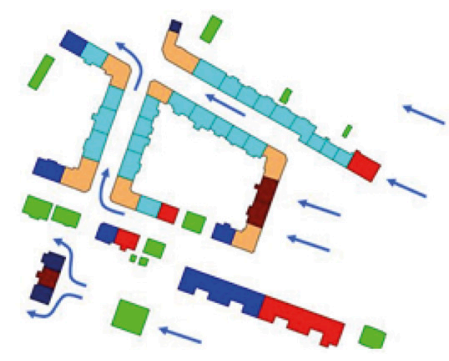

(b)

Type: 1

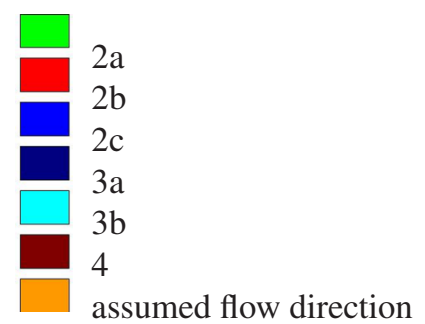

Figure 13: Examples for classification of real structure of settlement (Table 3): (a) Single house and row; (b) block and row; and (c) mixed structures. 


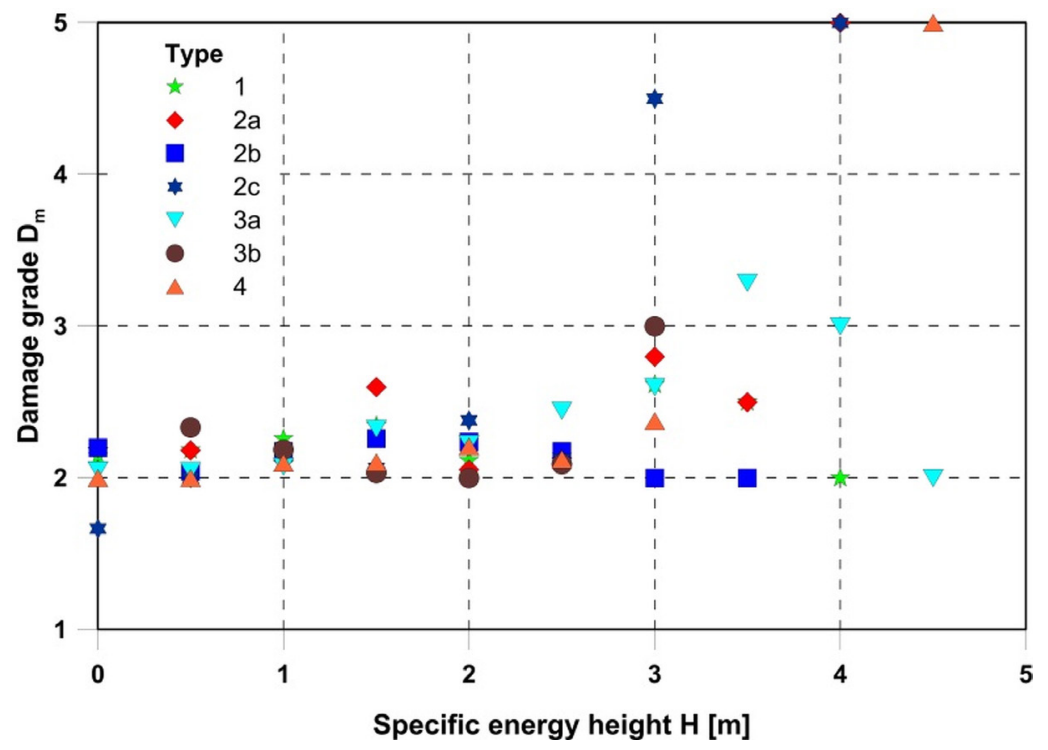

Figure 14: Mean damage $\mathrm{D}_{\mathrm{m}}$ grades depending on specific energy height $\mathrm{H}$, location of building and flow direction $[13,18]$.

flood event. Buildings are also often not orthogonal and tangential to the incident flow direction, so that a classification according to Table 8 is clearly not possible. In addition, the flow direction can be set for complex site conditions only by specifying a velocity vector.

The classification scheme in Table 8 is, therefore, to be understood as a first proposal and has to be revised using a larger database.

Figure 13 shows an attempt to classify different situations from the real development study areas, assuming a main flow direction according to the scheme in Table 8. Comparable to the procedure in Section 5.2, the mean damage grades $\mathrm{D}_{\mathrm{m}}$ are calculated at intervals of $\Delta H=0.5$ $\mathrm{m}$. The results are shown in Fig. 14. Due to the relatively small data density for several types according to Table 8, the results indicate no clear trend over the whole range of the intervals considered. However, it can be identified that the structural damage is higher for orthogonally streamed buildings (Type 1, 2a and 2c with the exception of Type $3 \mathrm{~b}$ ) than for tangentially streamed, like Type $3 a$ or Type $2 b$ at the end of a row of houses. Further investigations on a more comprehensive data set are necessary.

\section{SDF - LOSS PREDICTION}

In the developed microscale damage model, two types of damage functions (denoted by 'Specific Damage Functions' - SDF) are considered to quantify the expected loss (Table 9).

- SDF Type 1a (Fig. 15) are related to the building types [9,11,12], and SDF Type 1b (Fig. 16) to the vulnerability classes $[9,11]$. Both functions calculate the losses depending on the inundation level $h_{\mathrm{gf}}$, with a further consideration of the presence of a basement and the number of stories.

- SDF Type 2 (Fig. 17) transfers the calculated damage grades $\mathrm{D}_{\mathrm{m}}$ (with respect to the building type/vulnerability class of the building) into loss statements $[9,13]$. Also, these 
Table 9: Types of specific damage functions - SDF.

\begin{tabular}{|c|c|c|c|c|}
\hline $\begin{array}{l}\text { SDF } \\
\text { type }\end{array}$ & Input parameter & $\begin{array}{l}\text { Vulnerability } \\
\text { parameter }\end{array}$ & Building parameter & Impact parameter \\
\hline 1a & & Building type & Presence of cellar & Inundation level \\
\hline $1 b$ & & $\begin{array}{l}\text { Vulnerability } \\
\text { class }\end{array}$ & Number of stories & $\begin{array}{l}\text { over ground floor } \\
\left(h_{\mathrm{gf}}\right)\end{array}$ \\
\hline 2 & $\begin{array}{l}\text { Damage grade Di and } \\
D_{m} \text {, respectively }\end{array}$ & $-*$ & & \\
\hline
\end{tabular}

*Considered by the calculation of $\mathrm{Di}$ and $\mathrm{D}_{\mathrm{m}}$, respectively.

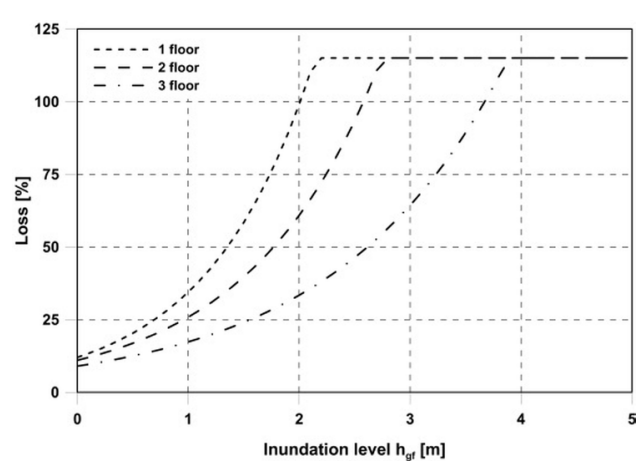

(a)

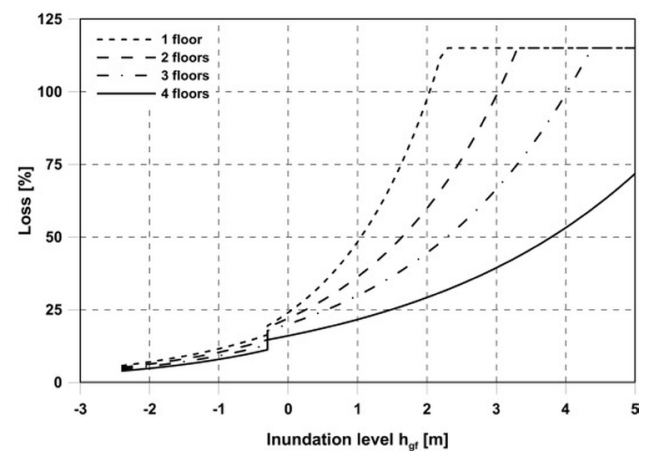

(b)

Figure 15: SDF Type 1a: (a) clay, without basement and (b) masonry, with basement.

functions consider the number of stories and the presence of a basement. Because the damage grade $\mathrm{D}_{\mathrm{m}}$ can also be determined by the specific energy height $H$, the consideration of the flow velocity is also possible by the calculation of losses $[9,13]$.

The functions can be applied to calculate the losses to the building structure (including building services). The main application is the general residential building stock. An application for other types of use should also be possible for similar building construction.

Both types of functions indicate the loss $(L)$ as a relative fraction of the replacement value, which can be calculated for a building in Germany using the so-called 'Normalherstellungskosten' (normal construction costs) [34,35]. Additional information, therefore, can be found in [9] and [11].

The SDF according to Eq. (5) are based mathematically on an exponential approach $[9,11-13]$. The control parameters A and B for the functions that are based on data set 1 can be taken from [9]

$$
\mathrm{L}\left(h_{\mathrm{gf}}\right)=\mathrm{A} \cdot \mathrm{e}^{\mathrm{B} \cdot h_{\mathrm{gf}}}
$$

Additional information concerning application and a discussion of the qualitative properties of the damage functions can be found in [9,11-13]. The derived damage functions shown in 


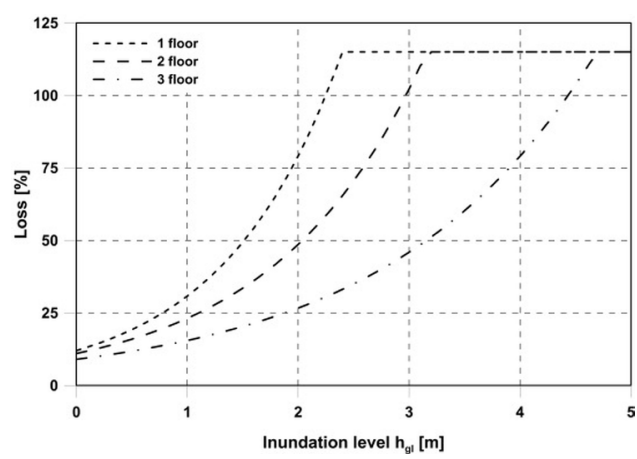

(a)

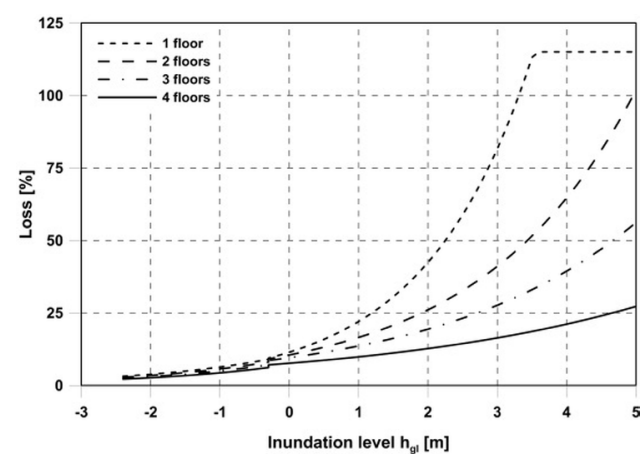

(b)

Figure 16: SDF Type 1b: (a) HW-B, without basement and (b) HW-D, with basement.

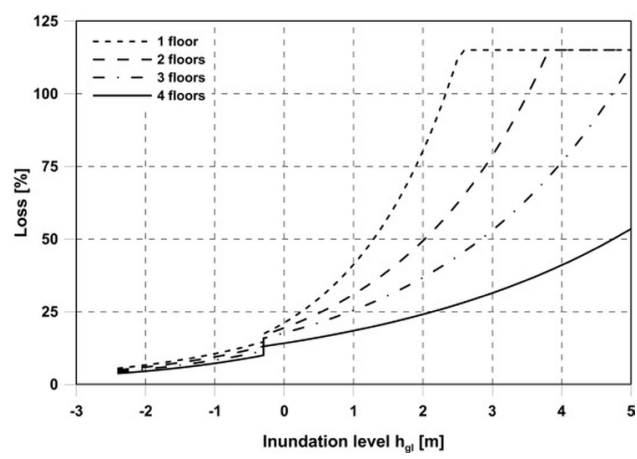

(a)

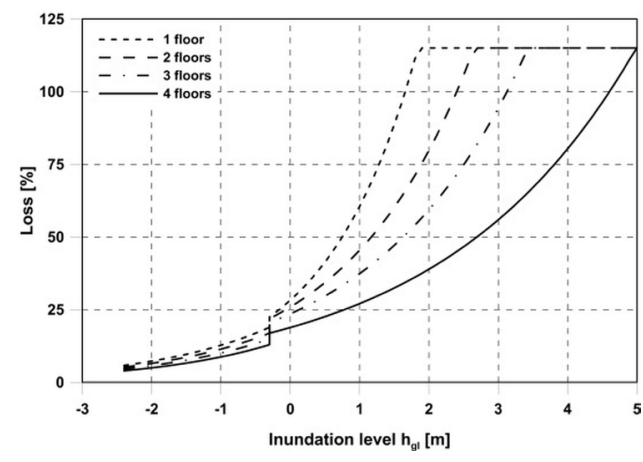

(b)

Figure 17: SDF Type 2: (a) damage Grade D2, with basement and (b) damage Grade D4, with basement.

Figs 15-17 include values above 100\% taking into account the demolition and disposal costs $[9,11,12]$. Studies for validating the damage model for different study areas show that both types of damage functions SDF lead to an engineering-based and realistic evaluation of flood damage [9-11].

More refined damage functions SDF Type 1a based on the 2008 state of data set 3 are derived in [12]. Further functions for the complete data set 3 are actually under preparation.

\section{CASE STUDIES}

The innovative options and advantages of the whole procedure are demonstrated by case studies from the 2002 flood in Saxony. With the developed SVF, the mean damage grade $\mathrm{D}_{\mathrm{m}}$ can be calculated for each individual building (microscale level) in the three study areas Döbeln, Eilenburg and Grimma (Fig. 5).

Since the exact address based cartographic representation is problematic for different reasons and can lead to uncertainty among the homeowners, an anonymous representation of the damage grades and the losses in a mesoscale level is preferable. Figure 18 shows study areas 
Döbeln

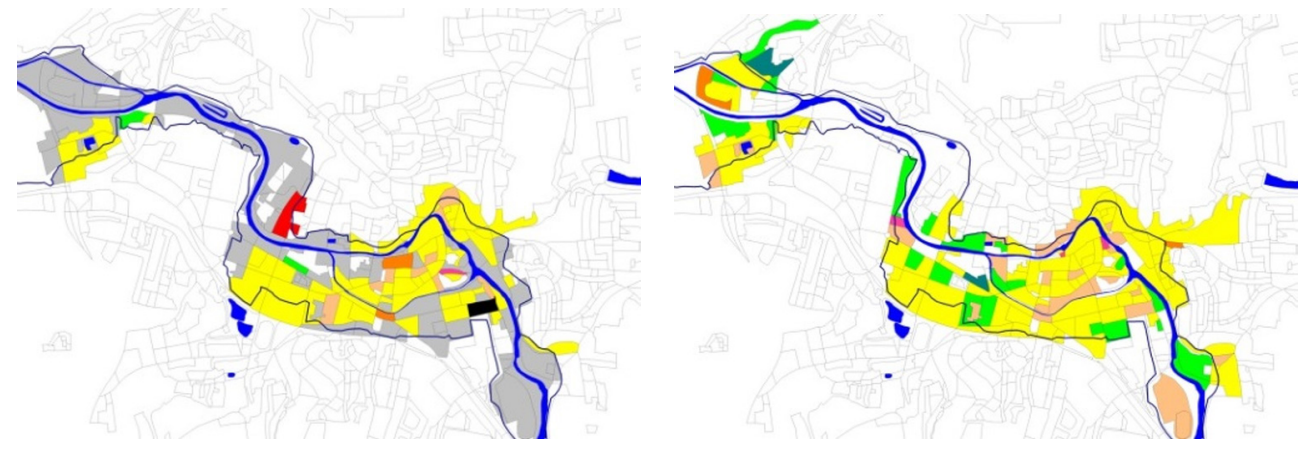

(a)

(b)

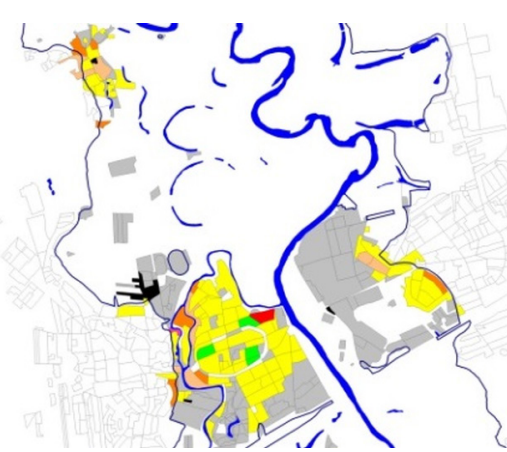

(c)

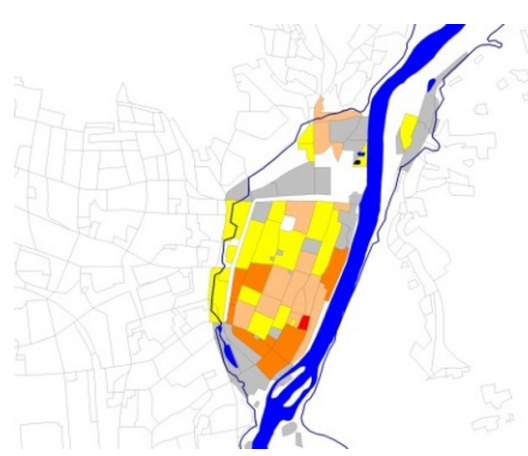

(e)

Mean damage grade MDm
Eilenburg

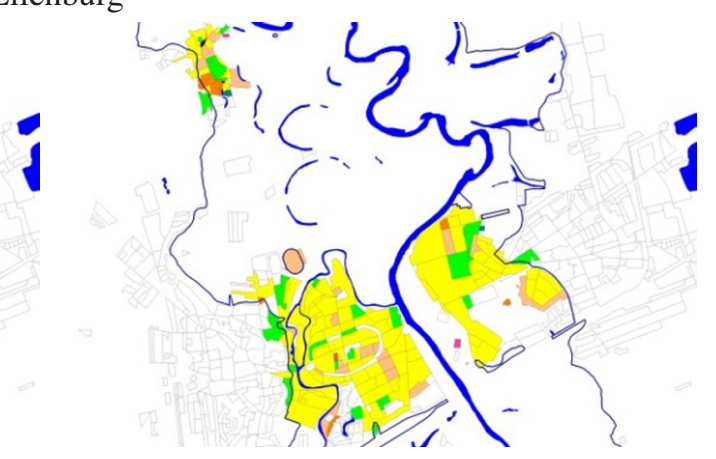

(d)

Grimma

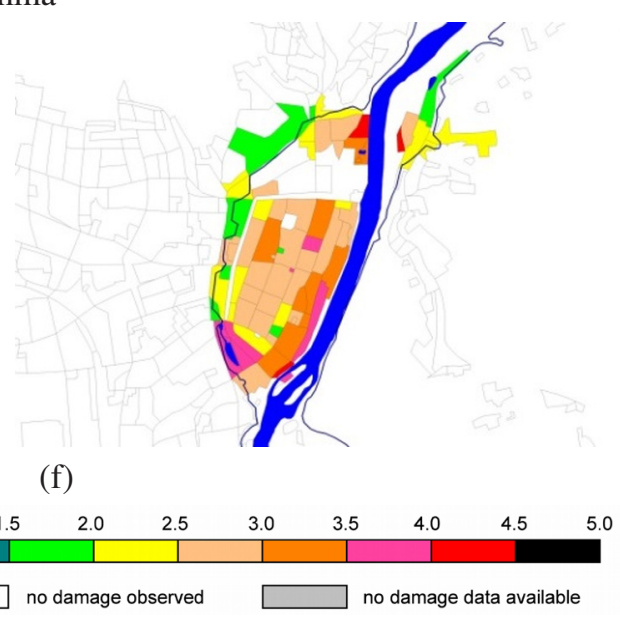

(f)

Figure 18: Mean damage grades $\mathrm{MD}_{\mathrm{m}}$ in the ATKIS land use areas (based on microscale calculation); Döbeln: (a) observed* and (b) re-interpretation (SVF Type 2b); Eilenburg: (c) observed* and (d) re-interpretation (SVF Type 1a); Grimma: (e) observed* and (f) re-interpretation (SVF Type $2 b)$. *Note: based on data set 3 . 
Döbeln

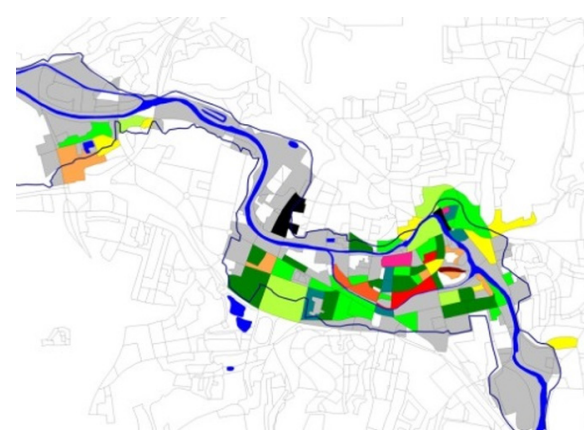

(a)

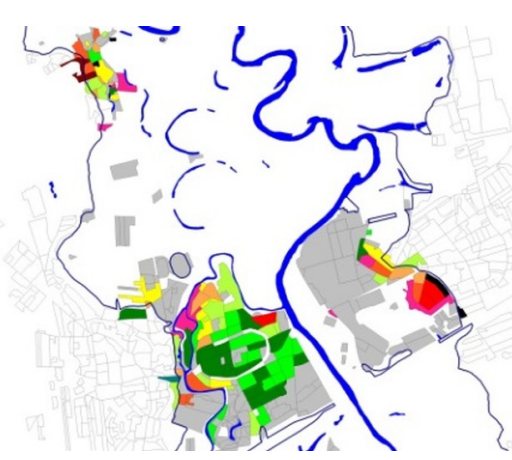

(c)

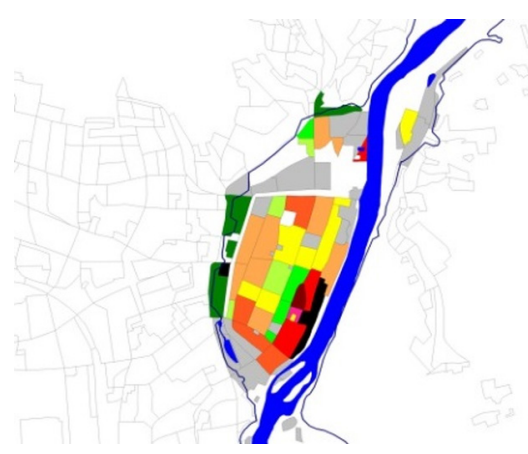

(e)

Loss [\%]

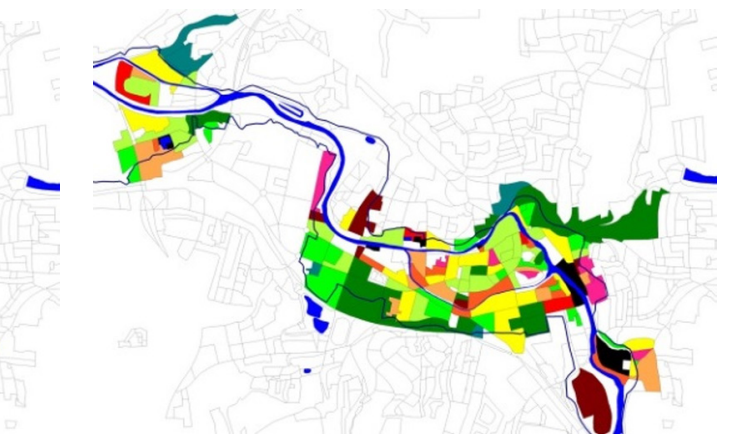

(b)

Eilenburg

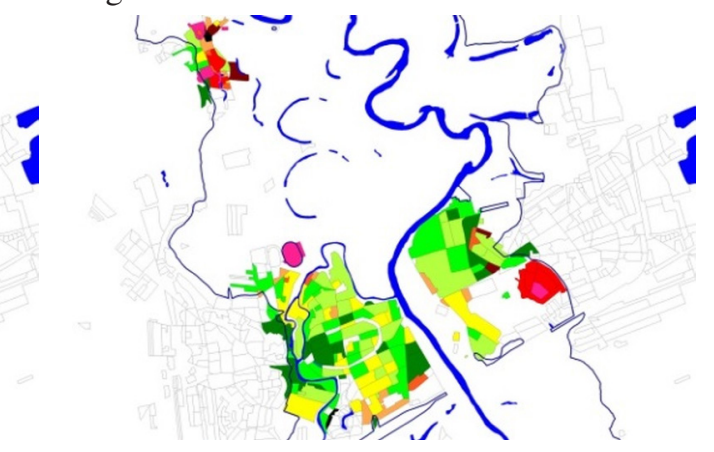

(d)

Grimma

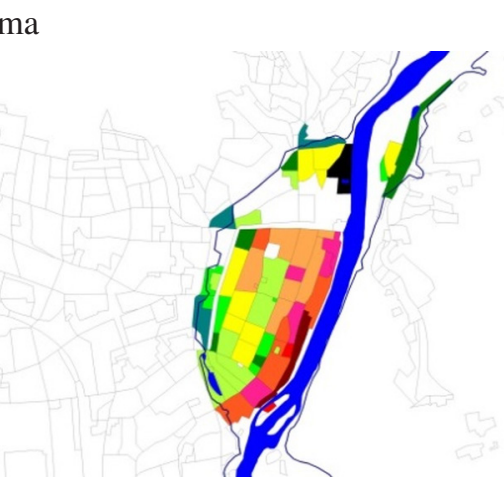

(f)

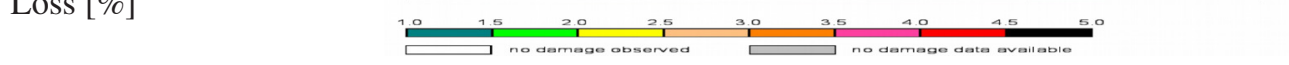

Figure 19: Relative losses in the ATKIS land use areas (based on microscale calculation). Döbeln. (a) observed* and (b) re-interpretation (SDF Type 1a); Eilenburg: (c) observed*; (d) re-interpretation (SDF Type 1b); Grimma: (e) observed* and (f) re-interpretation (SVF Type 2b, SDF Type 2). *Note: based on data set 3. 

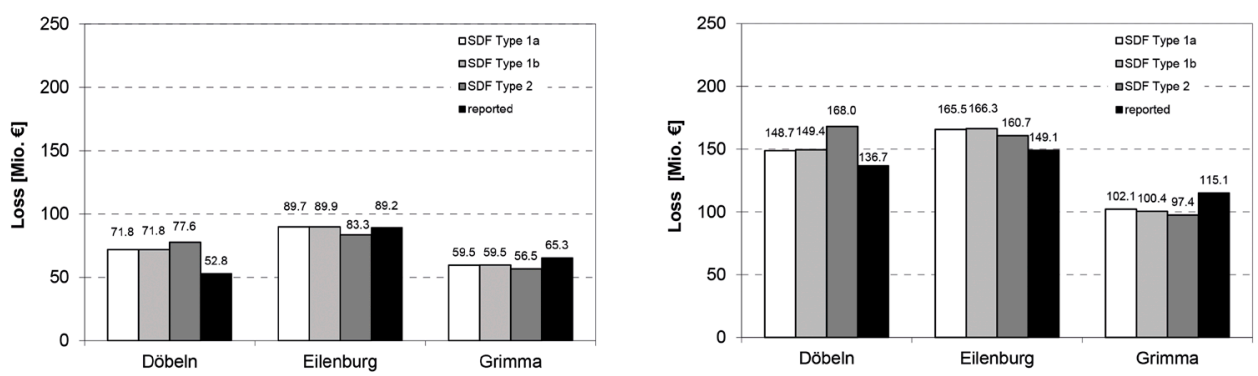

Figure 20: Comparison between calculated [9,18] and final reported losses [37]: (a) residential building stock and (b) entire building stock.

for the comparison of the calculated and the observed mean damage grades $\mathrm{MD}_{\mathrm{m}}$ in the land use areas according to the 'Amtliches Topographisch-Kartographisches Informationssystem' (ATKIS) for Germany [36], which are composed by the mean damage grades $\mathrm{D}_{\mathrm{m}}$ for the individual buildings. The damage grades for the individual buildings were additionally varied, based on their statistical distribution (see $[9,11]$ ).

The calculated and the observed structural damages show a good agreement in most of the land use areas. Larger differences in some other areas can be attributed to the fact that in these regions, the database concerning the observed damage cases is not complete.

For the study areas, loss statements calculated with the different damage functions are available according to the flow charts in Figs 2 and 3. For the reinterpretation with regard to the water level on the action side, damage functions SDF Type 1a and 1b [9] will be used. In a third calculation variant, first the mean damage grades $D_{m}$ are calculated with vulnerability functions SFV Type $2 b$ (with consideration of the flow velocity). These are then transferred with damage functions SDF Type 2 into loss statements.

The distribution of the observed relative losses in the study area Döbeln can be taken from Fig. 19a. The calculation in Fig. 19b is presented for the damage functions SDF Type 1a $[9,11]$. Figure $19 \mathrm{c}$ and d compares the observed losses and the reinterpretation in the study area Eilenburg for the damage functions SDF Type 1b [9,11]. Figure 19e and $\mathrm{f}$ shows the distribution of losses in Grimma, which are calculated for the resulting damage grades $\mathrm{D}_{\mathrm{m}}$ taking into account the flow velocity [13].

Areas with high loss concentrations can be clearly identified in Eilenburg and Grimma, which can give reasons to take special care on reconstruction measures in these areas.

The comparison of the predicted losses with the final official damage statistics of the SAB [37] shows a very good agreement for the residential building stock (Fig. 20a). This is true for all calculation variants (with and without consideration of the flow velocity) despite the different flooding characteristics in the study areas.

The slightly higher loss prognosis for the residential building stock in Döbeln is due to the fact that in the accumulated data of the SAB not all damage cases are included. In the study, 832 residential buildings are taken into account, compared with 681 in the damage statistics. It can be assumed that the remaining unconsidered damage cases were regulated by insurance. For the prediction of losses to the entire building stock (Fig. 20b), it has to be considered that the application of the vulnerability functions as well as the damage functions on non-residential buildings is only an approximation. 
The influence of the flow velocity can be seen more in the qualitative distribution of the damages and losses in the ATKIS land use areas. With the exception of the study area Döbeln, the effect of the flow velocity to the total loss is low (Fig. 20b), due to the moderate flow velocities $\left(v_{\mathrm{fl}}<2.5 \mathrm{~m} / \mathrm{s}\right)$. In Eilenburg and Grimma, the different reference levels of vulnerability functions lead to a minimal reduction of the loss of the residential buildings (see also [13]); this can be explained by technical model aspects.

Despite lower differences to the observed damage, it can be shown that realistic and detailed damage prognosis can be given with the developed vulnerability and damage functions.

\section{CONCLUSIONS AND PERSPECTIVES}

Based on a unified data elaboration, a model was developed to predict the structural damage of a building or of an affected building stock for specific flood scenarios.

With the provided tools, the structural damage can be evaluated uniformly and linked to the impact parameters. Frequently observed damage patterns are transferred into a scheme of damage grades.

The introduction of vulnerability classes enables the explanation of the scatter in the observed damage cases in a systematic manner. The variety of the building types can be reduced to the relevant parameters for the damage.

Vulnerability classes are defined and based on the damage data; the expected ranges of scatter of the predominant building types are determined.

The developed model provides tools for the prediction of structural damage of the building taking into account the specific building vulnerability, the inundation level and the flow velocity.

The inundation level $h_{\mathrm{gf}}$ or the specific energy height $H$ are used as suitable impact parameters. The presented damage functions provide reliable monetary losses for cost-benefit analyses on the basis of replacement costs.

Results are presented for different study areas on a microscale level. In all cases, remarkably good agreement between the predicted and the reported losses can be stated. First investigations with respect to the location of buildings, the direction of flow and the structural damage are also represented.

The conditions for the application of the methodology and the tools for the prognostic purposes, e.g. in the field of flood management plans or in the insurance industry, are therefore given.

The developed vulnerability functions SVF and the damage functions SDF have to be verified with a more comprehensive data set.

The heavy 2013 flood in Germany enables the application of the model in the study areas to a repeatedly affected building stock. The evaluation of the vulnerability and the plausibility of the developed functions have to be checked for such conditions.

For the application of the vulnerability-based damage functions SDF, a detailed building inspection is necessary, which is not always realizable due to cost and effort limitations.

For these cases, the methodology has to be transferred to the mesoscale level, although this may lead to significant decrease of quality.

Further studies, currently being carried out, use geodata on a microscale level. Combined with newly developed vulnerability-based damage functions (with respect to the building area), realistic loss statements can also be given. In these cases, reasonable assumptions about the distribution of building types or vulnerability classes in the study areas must be taken. 


\section{REFERENCES}

[1] Leitstelle Wiederaufbau, Augusthochwasser 2002, Schadensausgleich und Wiederaufbau im Freistaat Sachsen, Sächsische Staatskanzlei: Dresden, 2003

[2] MEDIS, Hochwasserschäden - Erfassung, Abschätzung und Vermeidung, Final Report of the RIMAX Research Project MEDIS: Methoden zur Erfassung direkter und indirekter Hochwasserschäden, eds., A.H. Thieken, I. Seifert, B. Merz, Oekom-Verlag, München, 2010.

[3] Deilmann, C., Naumann, T., Pflügner, W., Schanze, J., Calculation of flood damages in VERIS-Elbe - based on urban structural types and synthetic damage functions, Flood Risk Management Research. From Extreme Events to Citizens Involvement, eds., J. Schanze, Proceedings European Symposium on Flood Risk Management Research (EFRM 2007), 6-7th February 2007, Dresden, Germany. Dresden: IÖR, pp. 206-207, 2007.

[4] Penning-Rowsell, E.C., Johnson, C., Tunstall, S., Tapsell, S., Morris, J., Chatterton, J., Coker, A., \& Green, C., The Benefits of Flood and Coastal Defense: Techniques and Data for 2003, Middlesex University Press: London, 2003.

[5] Naumann, T. \& Rubin C., Abschätzung von Hochwasserschäden an der Bausubstanz von Wohngebäuden nach einem gebäudetypologischen VERIS-Elbe Ansatz, DWASeminar Erhebung, Aufbereitung und Verwendung von Hochwasserschadensinformationen: Neues und Bewährtes, DWA Deutsche Vereinigung für Wasserwirtschaft: Abwasser und Abfall, 2008.

[6] Grünthal, G. (ed.), Musson, R., Schwarz, J. \& Stucchi, M., European Macroseismic Scale 1998. Cahiers du Centre Européen de Geodynamique et de Seismologie, Volume 15, Luxembourg, 1998.

[7] Smith, K. \& Ward, R., Floods Physical Processes and Human Impacts, John Wiley \& Sons Ltd.: Baffins Lane, Chichester, 1998.

[8] Penning-Rowsell, C., Johnson, C., Tunstall, S., Tapsell, S., Morris, J., Chatterton, J. \& Green, C., The Benefits of Flood and Coastal Risk Management: A Handbook of Assessment Techniques, Middlesex University Press: London, 2005.

[9] Maiwald, H. \& Schwarz, J., Ermittlung von Hochwasserschäden unter Berücksichtigung der Bauwerksverletzbarkeit, EDAC-Hochwasserschadensmodell, Scientific Technical Reports 01-11, Zentrum für die Ingenieuranalyse von Erdbebenschäden, Universitätsverlag, Bauhaus-Universität Weimar, 2011.

[10] Schwarz, J. \& Maiwald, H., Berücksichtigung struktureller Schäden unter Hochwassereinwirkung. Bautechnik, 84(7), pp. 450-464, 2007. doi: http://dx.doi.org/10.1002/ bate.200710039

[11] Maiwald, H., Ingenieurmäßige Ermittlung von Hochwasserschadenspotentialen im mikroskaligen Bereich, Dissertation, Bauhaus-Universität Weimar, Schriftenreihe des Instituts für Konstruktiven Ingenieurbau, Heft, 2007.

[12] Schwarz, J. \& Maiwald, H., Ingenieurmäßigen Beschreibung der Schadenserwartung von Gebäuden unter Hochwassereinwirkung auf der Grundlage von Verletzbarkeitsklassen, Final Report to Project 24614375 by order of the Landestalsperrenverwaltung des Freistaates Sachsen. Earthquake Damage Analysis Center, Bauhaus-Universität, Weimar, 2009.

[13] Maiwald, H. \& Schwarz, J., Berücksichtigung der Fließgeschwindigkeit bei Hochwasser-Schadensmodellen, Bautechnik, 86(9), pp. 550-565, 2009. doi: http://dx.doi. org/10.1002/bate.200910056 
[14] Schwarz, J., Maiwald, H. \& Gerstberger, A., Quantifizierung der Schäden infolge Hochwassereinwirkung: Fallstudie Eilenburg, Bautechnik, 82(12), pp. 845-856, 2005. doi: http://dx.doi.org/10.1002/bate.200590247

[15] Sächsisches Staatsministerium des Innern: Expertises of the chambers of architects and engineers by order of Saxon State Ministry of the Interior, 2002.

[16] US Army Corps of Engineers (USACE), Risk-based analysis for flood damage reduction studies, Engineering Manual 1110-201619, 1996.

[17] Schwarz, J. \& Maiwald, H., Damage and loss prediction model based on the vulnerability of building types, Proceedings of the 4th International Symposium on Flood Defence, 6-8 May 2008, Toronto, Canada, 2008.

[18] Maiwald, H. \& Schwarz, J., Damage and loss prediction model considering inundation level, flow velocity and vulnerability of building types, 3rd International Conference on Flood Recovery, Innovation and Response, FRIAR 2012, Dubrovnik, Croatia, 2012. doi: http://dx.doi.org/10.2495/friar120051

[19] Schwarz, J. \& Maiwald, H., Empirical vulnerability assessment and damage description for natural hazards following the principles of modern macroseismic scales, 15th World Conference Earthquake Engineering, Lisboa, 2012, Paper 5652.

[20] Bundesministerium für Verkehr, Bau- und Wohnungswesen, Planen und Bauen von Gebäuden in hochwassergefährdeten Gebieten, Hochwasserschutzfibel, 2002.

[21] Schwarz, J. \& Maiwald, H., Von der Schadensaufnahme zur Verletzbarkeitsfunktion ein Ansatz aus den Ingenieurwissenschaften, Section 9.2 in Hochwasserschäden Erfassung, Abschätzung und Vermeidung, Final report of the RIMAX research project MEDIS: Methoden zur Erfassung direkter und indirekter Hochwasserschäden, eds., A.H. Thieken, I. Seifert \& B. Merz, Oekom-Verlag, München, 2010.

[22] Reese, S., Die Vulnerabilität des schleswig-holsteinischen Küstenraumes durch Sturmfluten, Fallstudien von der Nord- und Ostseeküste, Dissertation, MathematischNaturwissenschaftlichen Fakultät, Christian-Albrechts-Universität zu Kiel, www.sterr. geographie.uni-kiel.de/mare/Dissertation-SReese.pdf, 2003.

[23] National Tsunami Hazard Mitigation Program, Designing for Tsunamis: Background Papers, Chapter 5: Building design.

[24] Kelman, I., Physical flood vulnerability of residential properties in coastal, eastern England, Dissertation, University of Cambridge, UK, 2002.

[25] Roos, W., Damage to Buildings, DELFT Cluster: The Netherlands, http://www.library. tudelft.nl/delftcluster/PDF-files/DC1-233-9.pdf, 2003.

[26] Black, R.D., Floodproofing Rural Residences, Report no. EDA 77-088, US Department of Commerce, Economic Development Administration: Washington, DC, 1975.

[27] Sangrey, D.A., Murphy, P.J. \& Nieber, J.L., Evaluating the Impact of Structurally Interrupted Flood Plain Flows, Cornell University, Prepared for: Office of Water Research and Technology. Distributed by: NTIS. PB-247 552, 1975.

[28] Smith, D. I., Extreme floods and dam failure inundation implications for loss assessment. Proceedings of a Seminar Natural and Technological Hazards: Implications for the Insurance Industry, 1991, pp. 149-165, 1997.

[29] Scawthorn, C., Flores, P., Blais, N., Seligson, H., Tate, E., Chang, S., Mifflin, E., Thomas, W., Murphy, J., Jones, C. \& Lawrence, M., HAZUS-MH flood loss estimation methodology. II. Damage and loss assessment. Natural Hazards Review, 7, pp. 72-81, 2006. doi: http://dx.doi.org/10.1061/(asce)1527-6988(2006)7:2(72) 
[30] Department of Homeland Security, Federal Emergency Management Agency, Mitigation Division, Multi-hazard Loss Estimation Methodology, Flood Model HAZUS ${ }^{\circledR} \mathrm{MH}$ MR4, Technical Manual, 2009.

[31] Bundesamt für Wasserwirtschaft, Bundesamt für Raumplanung, Bundesamt für Umwelt, Wald und Landschaft, Naturgefahren Berücksichtigung der Hochwassergefahren bei raumwirksamen Tätigkeiten, Empfehlungen, http://www.bafu.admin.ch/publikationen/ publikation/00786/index.html?lang=de, 1997.

[32] Landestalsperrenverwaltung des Freistaates Sachsen, Erstellung von Hochwasserschutzkonzeptionen für Fließgewässer (Empfehlungen für Ermittlung des Gefährdungs- und Schadenspotenzials bei Hochwasserereignissen sowie für die Feststellung von Schutzzielen), 2003.

[33] Kreibich, H., Piroth, K., Seifert, I., Maiwald, H., Kunert, U., Schwarz, J., Merz, B. \& Thieken, A., Is flow velocity a significant parameter in flood damage modelling? Natural Hazards and Earth System Sciences, 5, pp. 1679-1692, 2009. doi: http://dx.doi. org/10.5194/nhess-9-1679-2009

[34] Bundesministerium für Raumordnung, Bauwesen und Städtebau, Normalherstellungskosten NHK 95, http://www.gutachterausschuss.de/NHK/NHK95.pdf, 1997.

[35] Bundesministerium für Verkehr, Bau- und Wohnungswesen, Normalherstellungskosten NHK 2000, www.wertvmg.de/IHK/WertR-2006_Anlage-7-NHK-2000.pdf, 2000.

[36] Arbeitsgemeinschaft der Vermessungsverwaltungen der Länder der Bundesrepublik Deutschland, AdV: ATKIS - Amtliches Topographisch-Kartographisches Informationssystem, http://www.atkis.de.

[37] Sächsische Aufbaubank (Saxony Relief Bank), Information to the losses on the residential and commercial building sector due to 2002 flood in Saxony, Excel table, submitted in $12 / 2012$.

\section{PHOTO CREDITS}

The pictures in Tables 3 and 5 and Fig. 10 are taken by the courtesy of the Earthquake Damage Analysis Center (EDAC) at the Bauhaus-Universität Weimar.

USED SOFTWARE:

Maps are created with the GIS program MapInfo Professional® 10.5

\section{REFERENCE OF GEODATA}

ATKIS ${ }^{\circledR}$-BASIS-DLM, @ Staatsbetrieb Geobasisinformation und Vermessung Sachsen 2009 MapInfo Professional Data Directory: Small data sets for Europe: Water and highways, Pitney Bowes Business Insight from Digital Map of the World GisNET data licensed to Pitney Bowes Business Insight by GISdata Limited. C GDC Ltd 1993.

Flooded areas in the Free State of Saxony - Flood August 2002 (State of elaboration: 11/2007): Representation on the basis of data of: Saxonian State Office for Environment and Geology, State Reservoir Administration of Saxony, Environmental Departments of the Regional Councils of Chemnitz, Leipzig and Dresden, State Capital Dresden/Environmental Department, Municipality of Chemnitz/Environmental Department, Municipality of Zwickau/ Environmental Department, Municipality of Olbernhau and City Council Meissen.

VG250, (C) German Federal Agency for Cartography and Geodesy (BKG), 2003. 